\title{
Aktör İlişkilerağı, Sağlık-Hastalık ve Suç: Şahsiyet Dizisi Üzerinden Bir Tartışma
}

\author{
ALI GÜNDÜZ* \\ agunduz9932@gmail.com \\ ORCID-ID: 0000-0002-7132-5481
}

\author{
GÜNNUR ERTONG ATTAR* \\ gunnurertong@mersin.edu.tr \\ ORCID-ID: 0000-0002-6933-7731
}

Öz: Bu çalışma, bir öznenin ilişki ağındaki dönüşümü, hastalık ve cinayet olguları temelinde ele almakta ve bu dönüşümü Şahsiyet dizisi örneğinde ve Aktör İlişkilerağı Kuramı (Actor Network Theory) bağlamında incelemektedir. Araştırmanın temel motivasyonu, bireysel bir yaşantının toplumsal bir etkiye dönüşümünden ve Şahsiyet'teki kurgunun her an gerçeğe dönüşebilme olasılı̆̆ından kaynaklanmaktadır. Çalışma, Diken ve Laustsen'ın" "Filmden bahsederken toplumdan, toplumdan bahsederken de filmden bahsederiz" ilkesinden hareket ederek, hastalığın seri cinayete evrilişine, biyopsikososyal bakış açısıyla ve Mertonin gerilimi (strain) temele aldığı suçluluk kavramıyla yaklaşmaktadır. Sonuçlar, bir hastalı̆̆ın bireyin yaşamında radikal etkiler bırakabileceğini ve haksızlikları görmezden gelmek gibi toplumsal ve kurumsal çatlakların birikip derin toplumsal yaralara dönüşerek bireysel adalet arayışlarına neden olabileceğini ortaya koymaktadır.

Anahtar kelimeler: Aktör İlişkilerağı Kuramı, Şahsiyet dizisi (2018), Sağlık ve hastalık sosyolojisi, Alzheimer, Bireysel adalet arayışı.

\section{Giriş̧}

Sinema tıpkı kaza yerinde kullanılan reflektörler gibi, başka kazaların olmaması için seyir halindekileri uyaran ve olaya sşık tutarak onu daha da görünür hale getiren önemli bir araçtır. Morin'e göre ${ }^{2}$; sinema bize başka yaşamları gözlemleme ve o yaşamlarla özdeşleşme olanağı tanıyarak muhafazakâr bir ev kadınının bir fahişeyle empati kurabilmesine fırsat verir. Bu nedenlerle sinema, toplumu okumak için etkili bir araçtır.

Toplum, insanların birbirlerinden izole olmadıkları, aksine birbirleriyle çeşitli güçteki bağlarla etkileşim halinde oldukları bir ağ (network) olarak kabul edilebilir. En ufak bir etkinin bile, ağın bir ucundan diğer ucuna kadar, farklı nitelikteki merkezle-

\footnotetext{
* Lisansüstü, Mersin Üniversitesi, Sosyal Bilimler Enstitüsü, Sosyoloji Ana Bilim Dalı.

** Dr. Öğr. Üyesi, Mersin Üniversitesi, Fen-Edebiyat Fakültesi, Sosyoloji Bölümü.

1 Bülent Diken ve Carsten Bagge Laustsen, Filmlerle Sosyoloji, çev., Sona Ertekin, İstanbul: Metis Yayınları, 2016, s.35.
}

2 Akt. Diken ve Laustsen, Filmlerle Sosyoloji, s.28. 
rine farklı dozlarda etki etme gücü vardır. Bu etki sürecinde gerek canlı gerek cansız birçok faktör, ilişkilerin boyutunu, sınırlarını, süresini ve niteliğini belirlemektedir. Örneğin bir hastalık, bireylerin tüm hayatını altüst edebilir. Suça karışma, düzenden memnuniyetsizlik, hak arama gibi konulardaysa bireyler hem kendi hayatlarını hem de etki edecekleri diğer hayatları değiştirme potansiyeliyle doludurlar.

Filmlerin “indirgenemez biçimde tarihi ve toplumsal” olduğunu söyleyen Ryan ${ }^{3}$, bu noktada haklıdır. Çünkü sinema, toplumsalın bir alt kolu olarak görev üstlenebilir. ${ }^{4}$ Bugün, sinema endüstrisi, ürünlerini küçük parçalar halinde sunduğu format olan dizilerde, bu özelliklerini koruyarak sürdürmektedir. Benjamin'in, düşüncelerini resimler ve alegorilerden hareketle aktaran Barok insanlarına yaptığ tik imge perspektifinde olduğu gibi ${ }^{5}$, dizilerdeki kişilerin, konuların ve nesnelerin geleceğe aktarılan ve kilden tabletler yerine dijital bellek kartlarının her bitine işlenen toplumsal ve kurgusal birçok düşünceyi anlamada yol gösterici olduğu düşünülmüştür. Bu çalışmada, bir hastalık durumundan doğan cinayet işleme kararını, farklı sosyolojik yaklaşımların kavramlarını kullanarak failin ve içinde bulunduğu ilişki ağının dönüşümünü araştırmaktadır.

Şahsiyet, bir Internet platformu olan Puhu TV'de 17 Mart 2018-8 Haziran 2018 tarihleri arasında üçer bölümlük parçalarla yayınlanmış, toplam 12 bölümlük dram, polisiye türünde bir Ay Yapım dizisidir. Dizinin yönetmeni Onur Saylak, senaristi Hakan Günday'dır. ${ }^{6}$ Dizinin adınınsa bir tesadüf olmadığı Atay’ın ${ }^{7}$ şu analizinde belirginleşir: İngilizce'de vicdan anlamına gelen "conscience" ve bilinç anlamına gelen "consciousness" kelimeleri etimolojik olarak Latince'deki "consire" kelimesine dayanır. Bu kelimeyse "yanlışı bilmek" anlamıyla, aslında Şahsiyet dizisinde Agah karakterinin sürekli aklını kurcalayan cinsel istismar olayını bilmesiyle oldukça ilişkilidir. Zaten Agah isminin sözlük anlamı "bilir, bilgili, haberli"dir. ${ }^{8}$ Yaşanmış bir istismar olayını bilen Agah, vicdani sancı duyduğu bu olayın bilincindedir ve hastalandıktan sonra daha cüretkâr bir intikam alma eylemine girişir. Çünkü bilinci oluşturan temel faktör olan hatırlama yetisini kaybetmesine neden olacak olan Alzheimer hastalığıyla tanışmıştır ve bundan sonraki hayatı artık koşuşturmalı bir cinayetler serisine dönüşecektir.

Dizinin ana karakterlerinden olan Agah Beyoğlu (Haluk Bilginer), İstanbul Beyoğlu'nda münzevi şekilde yaşayan emekli bir adliye memurudur. Eşi ölmüş, kızıysa yurtdışında yaşamaktadır. Kambura ${ }^{9}$ Adliyesi’nde çalıştı̆̆

3 Michael Ryan, "Sinema Politikaları: Söylem, Psikanaliz, İdeoloji”, çev., Hakan Erkılıç, Sinecine, 6/2 (2015), s.84. (erişim 24.05.2019).

4 Ryan, "Sinema Politikaları".

5 Diken ve Laustsen, Filmlerle Sosyoloji, s.34.

6 "Şahsiyet PuhuTV", erişim 27 Şubat, 2020, https://puhutv.com/sahsiyet-detay.

7 “Unutabilmenin 'Vicdani-Cinai' Ferahlığı!", erişim 26 Mayıs, 2019, http://www.cumhuriyet .com.tr/ koseyazisi/944765/Unutabilmeninvicdani-cinaiferahligi.html.

8 "Agah", erişim 3 Şubat, 2019, http://www.tdk.gov.tr/index.php?option=com_bts\&view=bts\&kat egoril =veritbn\&kelimesec $=4270$.

9 Dizi için kurgulanmış bir yerdir. Esasiye ilinin Kambura ilçesi olarak geçer ve 13400 nüfusa sahip 13 rakımlı bir bölgedir. Dizideki görüntülerse Bursa’nın Nilüfer ilçesinin Uluabat Gölü kıyısındaki Gölyazı Köyü’nde geçmektedir. Kambura bir yarımadadır. Olaylar ilerledikçe Ferdinand Tönniesci (1855-1936) anlamda birbirine 
mar olayı Agah’a aktarılmış fakat çözüme kavuşturmak için elinden bir şey gelmemiştir. 2007 ve 2011 yıllarında olayın baş sorumlusu olduğunu düşündüğü ağır ceza hâkimi Mehmet Yurtgil'i (Avni Yalçın) öldürmeye niyetlenmiş ancak başarılı olamamıştır. Daha sonra kendisine Alzheimer başlangıcı teşhisinin konmasıyla Agah, "zaten unutacağım” diyerek suçlu gördüğü herkesin haritasını çıkarmaya ve hepsini bir bir öldürerek geçmişle yüzleşmeye karar verir. Bu ölümlerin kovuşturmasından sorumlu polis Nevra (Cansu Dere) da bu hikâyenin en önemli parçalarından biri olarak karşımıza çıkar.

Çalışma özelinde problemi oluşturan konu; bireysel adalet arayışı ve sonucunda ortaya çıkan cinayetlerdir. Umut Vakfı'nın “Türkiye Silahlı Şiddet Haritası” 2019 Raporu’na ${ }^{10}$ göre 2019 yılında Türkiyede, 2211 kişinin öldüğü 3736 kişinin de yaralandığ toplamda 3623 silahlı olay medyaya yansımıştır. Bu silahlı olaylarda kullanılan silahların yaklaşık \%41'ini (132'si beylik tabancası olmak üzere 1465 olay) tabanca, \%39'unu (1402 olay) çeşitli tüfekler, \%20’sini (756 olay) kesici aletler oluşturmaktadir.

5237 sayılı Türk Ceza Kanunu'nun 81, 82 ve 83. maddeleri gereğince "kasten öldürme" olarak geçen cinayet terimi, "hayata karşı suçlar" kategorisinde yer alır. ${ }^{11}$ Hayata karşı işlenen suçlar kategorisi içindeyse 2018 verilerine göre \%39,1'lik bir dilim olarak "kasten öldürme" 28115 suç sayısıyla dikkat çekmektedir. ${ }^{12}$ Cinayet oldukça hayatın içinde bir olgudur.

Araştırmanın amacı, ortaya çıkan bireysel bir hastalıktan hareketle toplumsal bir durum olarak seri cinayetlere evrilen ilişki ağının dönüşümünü betimlemektir. Bu bağlamda araştırma süresince şu sorulara cevap aranmıştır:

- Hastalık olgusu kişinin ilişki ağını nasıl dönüştürebilir?

- Bireysel bir etki olarak hastalığın, toplumsal bir sonuç olarak seri cinayetlere dönüşümü nasıl olur?

- Agah’ın seri cinayetler işlediği bu ağda onun bireysel adalet arayışını tetikleyen ya da buna katkı sağlayan aktörler ve aktantlar kimlerdir?

- Bireysel adalet arayışı Agah’ın hayatını nasıl dönüştürmektedir?

sıkı sıkıya bağlı bir cemaat (gemeinschaft) oldukları göz önüne serilen Kambura; aile vurgusu, duygusal bağ, birbirini kollama, birincil ilişkiler, coğrafi ve toplumsal hareketin sınırlılı̆̆ı gibi özellikleriyle de bu fikri desteklemektedir [Martin Slattery, Sosyolojide Temel Fikirler, çev. Özlem Balkız, Gülhan Demiriz, Hacer Harlak, Cevdet Özdemir, Şebnem Özkan ve Ümit Tatlıcan. Ankara: Sentez Yayıncılık, 2017, s.59]. Kambura'ya giriş-çıkış, bir köprü ile yapılmaktadır. Bu ince köprü aslında metaforik olarak Kambura’nın, nevi şahsına münhasır bir portre çizmesiyle ve bağlı olduğu anakaradan ayrı özellikler sergilemesiyle eşdeğerdir. Nevra dokuz yaşındayken annesinin tayini nedeniyle Kambura'da bir sene bulunmuştur. Eskiden Kambura'da bulunan Nevra hem Kambura'yla ilişkili olan hem de orayı aslında hiç onaylamayan karakter olarak karşımıza çıkmaktadır.

10 Bu rapor, 2019 yılında Türkiye’nin yerel gazeteleri de kapsayan ve bu gazetelerin günlük olarak taranmasıyla oluşturulan bilgileri içermektedir (bkz: http://www.umut.org.tr/umut-vakfi-turkiye-silahli-siddetharitasi-2019/).

11 “Türk Ceza Kanunu”, erişim 26 Mayıs, 2019, http://www.mevzuat.gov.tr/ MevzuatMetin/ 1.5. 52 37.pdf, s.8987-8988.

12 “Adli İstatistikler 2018”, erişim 24 Mayıs 2019, http://www.adlisicil.adalet.gov.tr/istatistik_2018/

istatistik2018.pdf, s.26. 
- Yaşanan dönüşüm sonrası ortaya çıkan yeni ağlar nelerdir?

- Ağlarda yer alan aktör ve aktantlar birbirleriyle nasıl etkileşmektedir?

Türkçe literatürde sık rastlamadığımız Aktör İlişkilerağı Kuramından ${ }^{13}$ (Actor Network Theory-ANT) hareket etmesi, bu kuramın sinemada çok seyrek kullanılması, bireysel bir etkiden toplumsal bir etkiye dönüşen hastalık konusunun biyopsikososyal bir çerçeveden, sağlık ve hastalık sosyolojisi perspektifinden hareketle ortaya konulması, güncel ve ses getiren bir dizi olarak 9,2 $\mathrm{IMDb}^{14}$ puanlı (Şubat 2020 itibarıyla) Şahsiyet dizisinin örneklem seçilmesi bu çalışmayı önemli kılmaktadır. IMDb'nin dünyada gelmiş geçmiş en iyi 250 dizi sıralamasında Şubat 2020 itibarıyla 24. sırada olan Şahsiyet dizisii ${ }^{15}$, Şubat 2020 itibarıyla 266.000'i aşkın Puhu TV kullanıcısının favori listesindedir. ${ }^{16}$ Birçok dizi ve filmin herhangi bir ücret ya da üyelik olmadan izlenebildiği bu platformda ${ }^{17}$, diziyi favori listesine almadan ya da kayıtsız kullanıcı olarak da izleyebilecek binlerce kullanıcının olduğu düşünüldüğünde, Şahsiyet'in popülerliği ortadadır.

\section{Şahsiyet Dizisi Üzerine}

Kurgu bir karakter olan Agah'ın toplumu ne denli etkilediğine dair bir örnek her bölüm kaç kişiyi öldüreceğine dair oluşturulan bahislerdir. "Ailemizin Seri Katili İçimizden Biri Agah Beyoğlu” olarak nitelenen Agah’ın kaç kişiyi öldüreceğinin yanı sıra dans edip etmeyeceği, yeni bölümlerde rakı masası kurulup kurulmayacağı gibi bahisler de aynı sitede yer almaktadır. ${ }^{18}$ Aynı zamanda Şubat 2020 itibarıyla 136.000 kez okunmuş ve $573 \mathrm{kez}$ de farklı sosyal medya platformlarında paylaşılmış olan Onedio sanal platformunun "Hangi Şahsiyet Dizisi Karakterisin?” adlı testi oldukça

$13 \mathrm{Bu}$ kuramın isimlendirmesinin Türkçe tercümesinde: Aktör İlişkilerağı Kuramı [Aytül Kasapoğlu, "Giriş", Madalyonun İki Yüzü: Hastalık ve Sağlık, haz., Aytül Kasapoğlu, Ankara: Phoenix Yayınevi, 2008, s.13-37; Zuhal Yonca Hançer, “Sürdürülebilir Afet Yönetimi ve Kadın”, Doktora Tezi, Ankara Üniversitesi, 2009; Zuhal Yonca Odabaş ve Günnur Ertong, "Social Effects of Disasters as Actants: A Comparison of 1999 Marmara Earthquake, Turkey and 2004 Tsunami”, Ankara Üniversitesi Çevrebilimleri Dergisi, 3/2 (2011). (erişim 26.05.2019); Abdullah Cengiz Kayış, "Aktör İlişkilerağı Kuramı ve Barajlar: Yusufeli Barajı Örneği”, Karadeniz Araştırmaları, 14/56 (2017). (erişim 26.05.2019)], Ağ Düzeneği Kuramı [Tolga Torun ve Özüm Eğilmez "Yerleşiklik ve İlişkileri Anlamada Ağ Düzeneği Kuramı: Sosyolojik Bakış”, Dumlupınar Üniversitesi Sosyal Bilimler Dergisi, 42 (2014), (erişim 26.05.2019)], Aktör Ağ Kuramı/Teorisi [Jeffrey Miles, “Aktör Ağ Kuramı”, çev., Deniz Yetkin Aker, Yönetim ve Organizasyon Kuramları, haz., Mustafa Polat ve Korhan Arun, Ankara: Nobel Akademik Yayıncılık, 2016, ss.25-31; Töre Seçilmişler ve Zekiye Yenen, "Koruma Sorunsalına İlişkin Kuramsal Bir Değerlendirme: Kurumsalcı (Alan Yönetimi) ve Çoğulcu (Aktör Ağ Teorisi) Yaklaşımların Karşılaştırması”, Yıldız Teknik Üniversitesi Fen Bilimleri Enstitüsü Doktora Tezlerinden Üretilmiş Yayınlar, 3 (2011), (erişim 26.05.2019)], Aktör Şebeke Kuramı [Şadi Evren Şeker, "Aktör Ağ Teorisi (Actor Network Theory)", YBS Ansiklopedisi, 1/1 (2014), (erişim tarihi 26.05.2019)], Aktör Ağ Kuramı [Ebru Yetişkin, "Bir Başka Laboratuvar: B(A Toplum ve Bilim, 144 (2018), s.38-67], Fail Ağ Kuramı (Öznur Karakaş, “Toplumsal Hareketler, Ağlar ve Beden”, Toplum ve Bilim, 144 (2018), s.68-87; Ebru Kayaalp ve Onur Arslan, "Belirsizliğin Bilimi: Beklenen İstanbul Depremi ve Uzmanlar Antropolojisi”, Toplum ve Bilim, 144 (2018), s.124-145] gibi birden fazla isimlendirmeye rastlanmış olup bu çalışmada Aktör İlişsilerağı Kuramı tercümesi kullanılmıştır.

14 “Şahsiyet IMDb”, erişim 27 Şubat, 2020, https://www.imdb.com/title/tt7920978/.

15 “IMDb Top 250”, erişim 27 Şubat, 2020, https://www.imdb.com/chart/toptv/.

16 "Şahsiyet PuhuTV”.

17 “PuhuTV Yardım Merkezi”, erişim 26 Mayıs, 2019, https://puhutv.com/yardim-merkezi.

18 "Şahsiyet Dizisi Bahisleri”, erişim 26 Mayıs, 2019, https://www.bilemezsin.com/ ailemizin-seri-katiliicimizden-biri-agah-beyoglu-4-bolumde-sadece-1-kisiyi-oldurecek--50080. 
rağbet görmüştür. ${ }^{19}$ Ekşi Sözlük’teyse Şubat 2020 itibarıyla “şahsiyet (dizi)” başlığ1na toplamda 318 sayfalık (3178 adet) entry girilmiştir. ${ }^{20}$ Dizinin Instagram profilindeyse Şubat 2020 itibarıyla 17.000’i aşkın takipçi bulunurken ${ }^{21}$, dizi 17 Mart 2018 tarihinde Twitter'da TT (Trending Topic) listesine girmiştir ${ }^{22}$. Sertaç Özgümüş ve Güntaç Özdemir tarafından yapılan dizinin müzikleri, 26 Mart 2018 - 1 Nisan 2018 haftasında Spotify platformunda 7. siraya, iTunes platformunda ise 8. siraya kadar yükselmiştir. ${ }^{23}$ Oldukça popülerlik kazanıp çeşitli başarılar yakalayan ve 20 ülkeye satışı gerçekleștirilen dizi ${ }^{24}$, Ay Yapım ve Viacom ortaklığıyla Meksika'ya da uyarlanacaktır. ${ }^{25}$ NTV Dijital Medya Kıdemli Direktörü Can Birsay’ın 27 Kasım 2019'daki açıklamalarına göreyse dizi, 10 milyon takipçi tarafından 40 milyona yakın izlenme sayısına ulaşmıştır. ${ }^{26}$

Ayrıca pek çok matbu ve elektronik kaynakta Şahsiyet'i konu alan yazılar yayınlanmıştır. Agah’ın edimselliğini conatus ve habitus kavramlarından hareketle Bourdieu ve Spinoza perspektifinden ele alan ${ }^{27}$, Şahsiyet'in bir Türkiye alegorisi olduğu üzerinden şekillenen ${ }^{28}$, linç kültürü ve dizinin diyaloglarındaki toplumsal göndermeleri ön plana çıkartan ${ }^{29}$, bellek ve hınç kavramlarını temele alıp Nietzsche perspektifinden diziyi yorumlayan ${ }^{30}$, erillik, şiddet ve tacize odaklanan ${ }^{31}$, genel bir değerlendirme yaparak kötülük ve adalet gibi kavramlara dikkat çeken ${ }^{32}$, toplumsal pek çok realiteyi hatırlatan noktaları belirten ${ }^{33}$, Osmanlı'dan cumhuriyete geçiş dönemini modernleşme bağlamında Şahsiyet'le tartışan ${ }^{34}$, Agah ve Cemil karakterlerini hegemonik erkeklik perspektifinden çözümleyen ${ }^{35}$, Şahsiyet'in senaryosunu siyasi arka planı

19 “Hangi Şahsiyet Dizisi Karakterisin?”, erişim 27 Şubat, 2020, https://onedio.com/haber/hangi-sahsiyet-dizisikarakterisin-819481.

20 “Ekşi Sözlük Şahsiyet”, erişim 27 Şubat, 2020, https://eksisozluk.com/sahsiyet-dizi--5572 069 ?p=1.

21 “Şahsiyet Instagram”, erişim 27 Şubat, 2020, https://www.instagram.com /sahsiyetdizi/?hl=tr.

22 “Şahsiyet Twitter”, erişim 26 Mayıs, 2019, https://twitter.com/sahsiyetdizi/ status/975092 349863940097.

23 “Şahsiyet Dizisinin Müzikleri Listelerde Üst Sıraları Zorluyor!”, erişim 26 Mayıs, 2019, http://www.ranini.

tv/haber/30567/1/sahsiyet-dizisinin-muzikleri-listelerde-ust-siralari-zorluyor.

24 “Şahsiyet Dizisi Satış Sayısı”, erişim15 Aralık, 2019, https://www.birgun.net/haber/haluk-bilginer-e-odul-

kazandiran-sahsiyet-dizisi-hakkinda-bilmeniz-gerekenler-277757.

25 “Şahsiyet Dizisi Meksika’ya Uyarlanıyor”, erişim 26 Mayıs, 2019, https://neizledik.com/sahsiyet-dizisi-

meksikaya-uyarlaniyor/.

26 “Şahsiyet Dizisi İzlenme Sayısı”, erişim 15 Aralık, 2019, https://www.ntv.com.tr/sanat/emmy-odulu-

sahsiyete-ilgiyi-20-kat-artirdi-puhutvde-ucretsiz-izle,uXf_MYPdg025Ole1hQxcKA.

27 Ali Gündüz, "Şahsilikten Uzaktır Şahsiyet: Şahsiyet (2018) Dizisinin Düşündürdükleri Üzerine”, Pharmakon Felsefe Dergisi, 5 (2018).

28 "Bir Türkiye Alegorisi: Şahsiyet Dizisi Üzerine”, erişim 26 Mayıs, 2019, http://www.birikim dergisi.com/ guncel-yazilar/9063/bir-turkiye-alegorisi-sahsiyet-dizisi-uzerine\#.XGX_6ugzZPY.

29 Arzu Şahin, “Unutmak En Büyük Cinayettir”, Hayal Perdesi, 65 (2018).

30 “Şahsiyet Dizisindeki Unutma-Şahsiyet İlişkisinin Nietzscheci Görünümleri”, erişim 26 Mayıs 2019,https:// dusunbil.com/sahsiyet-dizisindeki-unutma-sahsiyet-iliskisinin-nietzschecigorunumleri /.

31 “UNUTMA/Şahsiyet Dizisi Üzerine”, erişim 26 Mayıs, 2019, https://www. dirensanat.com/2018/ 07/22/zehraipsiroglu-unutma-sahsiyet-dizisi-uzerine/.

32 “Şahsiyet Blog”, erişim 26 Mayıs, 2019, https://neokudumneizledim.blogspot.com/ 2018/11/dizi-incelemesisahsiyet.html.

33 “Şahsiyet: Dizi Finali Bize Neler Anlattı?”, erişim 26 Mayıs, 2019, http://sinekafe.com/sahsiyet-dizi-finalibize-neler-anlatti/.

34 “Şahsiyet Aslında Kimdi?”, erişim 26 Mayıs, 2019, http://www.eskimeyenkitaplar.com/sahsiyet-aslindakimdi/.

35 Züleyha Özbaş Anbarlı. “Dijital Televizyon Dizilerinde Hegemonik Erkeklik”, Erciyes İletişim Dergisi, 1 (2019). (erişim tarihi 26 Mayıs, 2019). 
yansıtmadığı için eleștiren ${ }^{36}$, Haluk Bilginer'in Emmy Ödül Töreni’nde yaptığ nulmasında değindiğ $i^{37}$ "toplumsal hafıza kaybı/toplumsal Alzheimer" kavramıyla diziyi trajedi temelinde çözümleyen ${ }^{38}$, Cemil karakteri üzerinden "patriarkal kapitalizm" yorumu yapan ${ }^{39}$, dizinin trans birey Naz Çörtük karakteri temelinde gerekli çözümü sunmadığını eleştiren ${ }^{40}$, kadın komiser Nevra karakteri üzerinden dizideki kadın temsilini çözümleyen ${ }^{41}$, rasyonalite-irrasyonalite ve sosyopolitik boyutta diziyi inceleyen ${ }^{42}$, Alzheimer hastalığının bilişsel süreçleri ve klinik çerçevesi üzerinden diziyi yorumlayan ${ }^{43}$, dizinin toplumsal hafıza kaybını çok iyi ortaya koyduğunu Türkiye tarihinden örnekler vererek öven ${ }^{44}$ ve seri cinayet olaylarına odaklanan ${ }^{45}$ birçok metin Şahsiyet üzerinde farklı açlardan düşünmemize yardımcı olmuştur. Aynı zamanda dizi; 2018 yılı Ayaklı Gazete TV Yıldızları Ödül Töreni’nde "En İyi İnternet Dizisi Dijital Platform" ${ }^{\prime 6}$, Galatasaray Üniversitesi’nin düzenlediği EN Ödülleri’nde "Yllın En İyi İnternet Dizisi”" Ödülleri’nde "Yllın En İyi Dizisi”" ve Türk Tip Öğrencileri Birliğiınin düzenlediği ödül töreninde "En İyi İnternet Dizisi" ${ }^{49}$ kategorilerinde ödül kazanmıştır. Ayrıca dizide Agah Beyoğlu karakterini canlandıran Haluk Bilginer, 47. Uluslararası Emmy Ödülleri’nde "En İyi Erkek Oyuncu" ödülünü almıştır..$^{50} \mathrm{Bu}$ ödülden sonra \#Şahsiyet ve \#HalukBilginer hashtagleri Twitter'da TT (Trending Topic) listesine girmiştir. ${ }^{51}$ Agah'n kızı olan Zuhal karakterini canlandıran Şebnem Bozoklu, bu performansı ile Orta Doğu Teknik Üniversitesi Medya Müzik Ödülleri’nde "Yılın En İyi Kadın Oyuncusu" ödülünü kazanmıştır. ${ }^{52}$ Dizideki Nevra karakteri performansı ile Cansu Dere de Yıldız Teknik Üniversitesi İşletme Kulübü 17. Yılın Yıldızları Ödülleri’nde

36 "Şahsiyet: 'Bu Dizide AKP Yokmuş Gibi Davranıyoruz”, erişim 26 Mayıs, 2019, https://gazete hayir.com/ sahsiyet-bu-dizide-akp-yokmus-gibi-davraniyoruz-arif-mutlu/amp/.

37 “Emmy Ödülleri Cumhuriyet Gazetesi”, erişim 15 Aralık, 2019, http://www.cumhuriyet.com.tr/video/ video/1704458/iste-haluk-bilginerin-odul-alirken-yaptigi-tarihi-konusma.html.

38 “Ya Alzheimer Ya Cinayet: Bir Şaheserdir Şahsiyet!", erişim 15 Aralık, 2019, https://t24.com.tr/yazarlar/ tayfun-atay-pazar/ya-alzheimer-ya-cinayet-bir-saheserdir-sahsiyet,24668.

39 “Şahsiyet'in Düşündürdükleri...”, erişim 15 Aralık, 2019, http://www.ekdergi.com/sahsiyetin-

dusundurdukleri/.

40 “Şahsiyet Dizisinin Trans Kadını Naz’ın Sorunlu Temsili”, erişim 27 Şubat, 2020, https://t24.com.tr/yazarlar/ hande-cayir/sahsiyet-dizisinin-trans-kadini-naz-in-sorunlu-temsili-hakkinda,25106.

41 Armoni Bayar, "Woman Representation in Turkish Detective Series: Şahsiyet", International Perspectives on Feminism and Sexism in the Film Industry, haz. Gülşah Sarı ve Derya Çetin, ABD: IGI Global, 2020, s. 229-253. 42 Fırat Mollaer, Yerliciliğin Retoriği, Ankara: Phoenix Yayınevi, 2018, s. 83-103.

43 Hande Kaynak ve Merve Denizci Nazlıgül, “Alzheimer Hastalığına Bilişsel Süreçler ve Klinik Çerçeveden Bakış: Şahsiyet Dizisinin Kritik İncelemesi”, AYNA Klinik Psikoloji Dergisi, 6 (2019).

44 “Şahsiyet”, erişim 27 Şubat, 2020, https://www2.karar.com/yazarlar/salih-cenap-baydar/sahsiyet-12563.

45 “Türk Seri Katil Dizisi”, erișim 26 Mayıs 2019, https://unifestal.com/seriefilm/turk-seri-katil-dizisi-sahsiyet/. 46 “Ayaklı Gazete TV Yıldızları”, erişim 26 Mayıs, 2019, http://www.ayakligazete.com/ayakli-gazete-yilin-enleribelli-oldu-2/.

47 “Galatasaray Üniversitesi EN Ödülleri”, erişim 26 Mayıs, 2019, https://www.ntv.com.tr /sanat/ sahsiyet2018in-en-iyi-internet-dizisi-secildi,Scw3ymGd306d06-Fa9o_zQ.

48 “ODTÜ Medya Müzik Ödülleri”, erişim 26 Mayıs 2019, https://neizledik.com/odtuden-sahsiyet-ve-sebnembozokluya-odul/.

49 “Türk Tip Öğrencileri Birliği”, erişim 26 Mayıs, 2019, https://fav10.net/forum /threads/t\%C4\% B1p\%C3\%96\%C4\%9Frencilerinden-\%C5\%9Eahsiyete-\%C3\%96d\%C3\%BCl.286425/.

50 “2019 International Emmy Awards”, erişim 15 Aralık, 2019, https://www.iemmys.tv/2019-international-

emmy-winners-announced-at-gala-in-new-york/.

51 "Emmy Ödülleri Cumhuriyet Gazetesi".

52 “ODTÜ Medya Müzik Ödülleri”. 
“2018 Yılının En Beğenilen Kadın Dizi Oyuncusu” ödülüne layık görülmüştür. ${ }^{53}$

\section{Kuramsal Yaklaşım}

Bu başlık altında sağlık-hastalık sosyolojisi, Aktör İlişkilerağı Kuramı ve kriminal sosyolojinin çalışmada kullanılan kavramlarına yer verilecektir.

\section{Sağlık-Hastalık Sosyolojisi ve Biyopsikososyal Yaklaşım}

Karmaşık bir organizma olan insan bedeninin hayatta kalabilmesi için sağlıklı bir yapıya ihtiyacı vardır. Sağlık olgusunun karşı cephesindeyse hastalık olgusu bulunur. Hastalık kavramını farklı düzeylerde ele almak mümkündür. Bunlar: rahatsızlık (illness), uzman teşhisi konulmuş rahatsızlık/hastalık (disease) ${ }^{54}$ ve yarı sağlıklılıktır (ill health) ${ }^{55}$. Rahatsızlık (ilness), daha çok bireyin ve kültürün sübjektif bir şekilde hastalığa yüklediği anlamken, uzman teşhisi konulmuş rahatsızlık/hastalık (disease) ise bir doktorun uzmanlık bilgisi dahilinde nesnel ve ampirik bir şekilde konulan teşhistir. ${ }^{56}$ Yarı sağlıklılık (ill health) ise, insanların her ne kadar tam hasta olmasalar da karşıtların birliği (unity of opposites) ilkesinden hareketle sağlık ve hastalığın özelliklerini birlikte bulundurma durumunu işaret etmektedir. ${ }^{57}$

Sağlık ve hastalığın bireye özgü olmayıp birtakım biyolojik, sosyal ve psikolojik faktörün bileşiminden meydana geldiği görüşü, sağlık-hastalık sosyolojisinin kavramsal kırılma noktalarındandır. Çünkü birey, içinde yaşadığı toplumdan bağımsız olarak düşünülemez ve bireyin bir kimlik edinmesi bedeniyle başlayan bir süreçtir. ${ }^{58} \mathrm{Bu}$ açıdan bakıldığında sağlık-hastalık sosyolojisine önemli katkılardan birini yapan Engel’e göre sağlık ve hastalık; biyolojik, psikolojik, sosyolojik vd. pek çok alana indirgenemeyecek kadar geniş bir alandır. ${ }^{59}$ Herhangi bir hastalık durumunu açıklarken içinde bulunulan sosyal bağlam ve toplum tarafından ele alınan tamamlayıcı rol göz ardı edilmemelidir. ${ }^{60}$ Çalışma özelindeyse Agah'ın hastalığının, hayatını psikolojik, etik, vicdani, kriminal, biyolojik ve sosyolojik pek çok boyutta etkilediğini görürüz.

\section{Aktör Illişkilerağı Kuramı}

1980'lerin ikinci yarısında şekillenen Aktör İlişkilerağı Kuramı, Latour, Callon ve Law’un öncülüğünde bilim, teknoloji ve toplum çalışmalarında kullanılmıştır. Birçok olayın nicel olarak ortaya koyulduğu laboratuvar ortamı, sosyal bilimlerin çözmeye çalıştığı pek çok problem için de örnek teşkil ederek ilişki ağı fikrini dogurmuştur. Çalışmada adını bu fikirden alan kuramın önemli kavramları ve arka

53 "YTÜ İşletme Kulübü 17. Yllın Ylldızları Ödülleri’, erişim 19 Kasım, 2019, https://www.ayyapim. com/tr-tr/ odullerimiz.

54 Erhan Tecim. Sağllk Sosyolojisi, Konya: Çizgi Kitabevi, 2018, s.15-18.

55 Kasapoğlu, "Giriş", s.15-22.

56 Nurşen Adak, "Sağllk Sosyolojisinin Temel Kavramları", Sağllk Sosyolojisi, haz., Mevlüt Özben, Erzurum: Atatürk Üniversitesi Açık Öğretim Fakültesi Yayınları, 2016, s.5.

57 Kasapoğlu, "Giriş", s.20-22.

58 Zafer Cirhinlioğlu. Sağllk Sosyolojisi, Ankara: Nobel Akademik Yayıncllık, 2001, s.94.

59 George L. Engel, "The Need For a New Medical Model: A Challenge for Biomedicine", Science, 196/4286 (1977). (erişim 26.05.2019); George L., Engel. “The Clinical Application of the Biopsychosocial Model”, American Journal of Psychiatry, 137 (1980). (erişim 26.05.2019).

60 Engel, “The Need", s.196-197. 
planı açıklanacaktır. Latour’a göre ağ; "enformasyonun her bir parçasının, deforme olmaksızın anlık ve aracısız olarak taşınması anlamına gelmektedir" ${ }^{61} \mathrm{Bu}$ ilişkiler ağının itici gücü/öznesiyse aktör (actor) ya da aktant (actant) olarak adlandırılır. ${ }^{62}$ $\mathrm{Bu}$ süreçte aktör ya da aktantlar, aracı (intermediary) ve arabulucu (mediators) rolüne bürünebilmektedirler. ${ }^{63}$ Aracı rolü, ilişki ağına hayati bir etkide bulunmaz ama kimyadaki katalizör gibi ilişkinin ortamda akışını sağlar. Arabulucu rolüyse aracı rolünün aksine ilişkiye etki edip yönlendirir. Örneğin bir köprü inşaatının akışını sağlayan bilgisayar bir aracıdır. Fakat çizim ya da hesap için bilgisayarda kullanılan programlar hayati öneme sahip bir role bürünerek arabulucu rolüne geçmektedir. Kuramın hastalık temelindeki ana hatları Şekil 1'de görülmektedir.

İLKDURUY

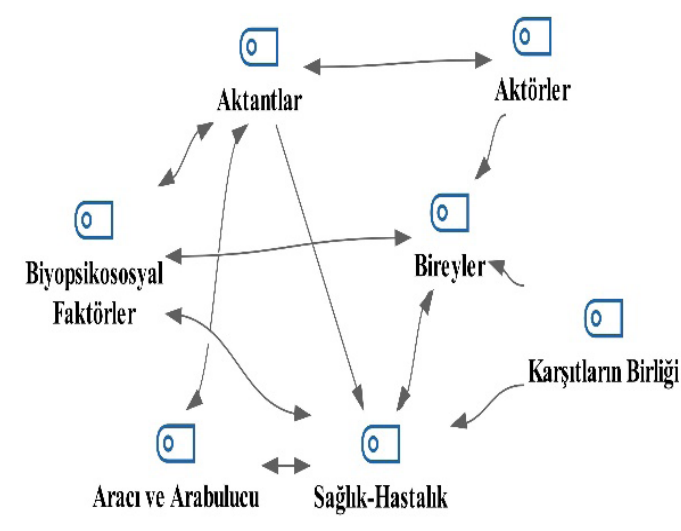

İkínci bURUM

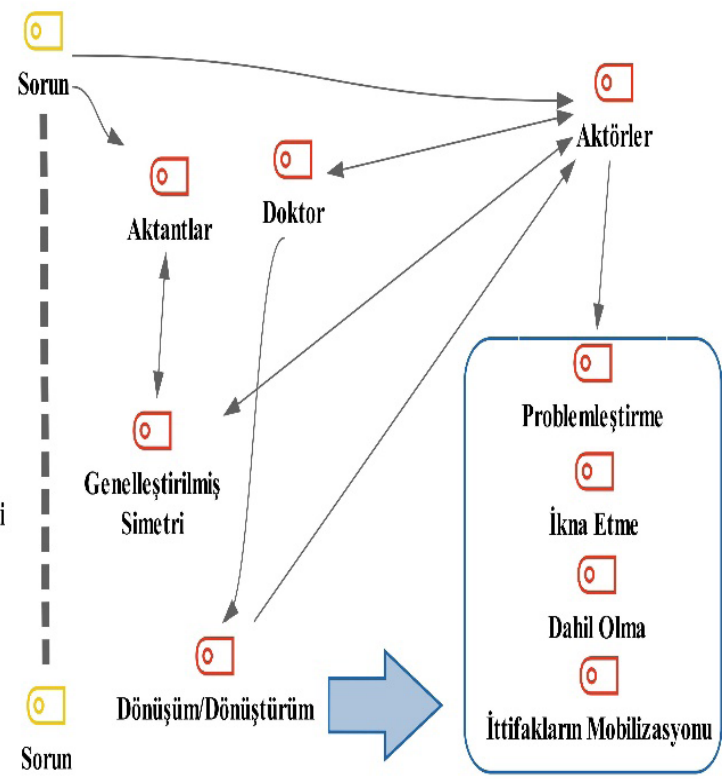

Şekil 1: Hastalık Öncesi ve Sonrasındaki Durumun Aktör İlişkilerağı Kuramı Çerçevesinden Görünümü

Callon'a göre ${ }^{64}$ dönüşüm/dönüştürüm (translation) süreci dört aşamadan oluşur: problemleştirme (problematization), ikna etme (interessement), dahil olma (enrollment), ittifakların mobilizasyonu (mobilization of alliances). Problemleştirme aşamasında baş aktör sorunu tespit eder ve kendi konumunu buna uygun olarak belirler. İkna aşamasında baş aktörün dışındaki ağ öznelerinin çeşitli yollarla ağa

61 Latour 1999'dan akt. Aylin Tutgun-Ünal, “Sosyal Medya Bağımlılığı: Üniversite Öğrencileri Üzerine Bir Araştırma”, Doktora Tezi, Marmara Üniversitesi, 2015, s.18.

62 Bruno Latour, Reassembling the Social: An Introduction to Actor-Network-Theory, Oxford: Oxford UniversityPress, 2005.

63 Mohammad Malla Mahmoud, “Bir Mimari Tasarım Sürecinin Aktör Ağ Teorisi ile Okunması”, Yüksek Lisans Tezi, İstanbul Teknik Üniversitesi, 2015, s.8.

64 Akt. Zuhal Yonca Odabaş, Sürdürülebilir Afet Yönetimi ve Kadın, Ankara: Ankara Üniversitesi Rektörlüğü Yayınları, 2010, s.55. 
dahil edilme sürecindeki efor kastedilir. Dahil olmada ise diğer aktör ve aktantlar ağa dahil olarak ilişkiye katılmışlardır. Son adım olan ittifakların mobilizasyonunda ise baş aktörün yönlendirmesiyle ilişki ağı şekillenir ve ağ özneleri kendi içlerinde etkileşirken bulundukları ağ da diğer ağlarla etkileşime girer.

Toplum, sürekli değişen bir yapıdır. Uzunca bir süre bu değişimin sadece insan (human) tarafından yönlendirildiği düşünülse de özellikle Tarde’ın katkılarıyla toplumsal değişim sürecinde insan olmayan (non-human) faktörlerin de etkin rol oynayabileceği fikri öne çıkmıştır. Bu durumu Tarde şöyle açılar: "a) insan etkileşimlerini anlamak için doğa ve toplum ayrımı önemsizdir; b) makro/mikro ayrımı toplumun nasıl oluştuğunu anlamaya dair çabaların önünü tıkamaktadır”. ${ }^{65} \mathrm{Bu}$ değişim sürecinde gerek insan gerekse insan olmayan faktörler değişimi başlatan, yönlendiren ve de başka bir değişim için şu anki durumu sonlandıran bir nitelik sergilemişlerdir. Örneğin bir silahı pasif olarak değil de bir kişinin bir kişiye doğrulttuğunu düşünelim. Bu silah artık bir ilişki ağının aktantı haline gelmiştir. ${ }^{66}$

Law’a göre bu kuramda; "varlıklar arasındaki farklılıklar yerine ilişkilerdeki karmaşıklıklar vurgulanmaktadır" ${ }^{67}$ Örneğin bir savaş, ağaçlandırma yasası ya da cinayet gibi kararlar, var olan toplumsal düzeni etkileyecek olup bir insan tarafindan verilmiştir. Aynı şekilde, doğal afet ve hastalık konularının başını çektiği insan olmayan faktörler işin içine girdiğindeyse bu değişimin önderi kimi zaman bir deprem kimi zaman HIV virüsü kimi zaman da bir teknolojik gelişme olabilmektedir. Kuramda "genelleştirilmiş simetri (generalized symmetry)", Aktör İlişkilerağı Kuramının temel ilkesi olup "tüm varlıkların/oluşumların eşit derecede eylemde bulunma kapasitesine sahip olması" ${ }^{38}$ olarak açıklanmaktadır.

Duygulara da ilişkileri şekillendirmesi bağlamında yer veren Latour, "dert edilen meseleler" anlayışıyla ağın şekillenebileceğini belirtir. ${ }^{69}$ Rodriguez-Giralt ${ }^{70}$ bu önermeye bir çevreci grubun, kuşlara ve çevreye duygusal bağlar hissettiğini ve bu hislerinin de onları eyleme sevk etmesi örneğini verir.

İlişkiler ağında ortaya çıkan etkileşimler birtakım göstergebilimsel materyalleri de doğurmakta ve bu materyaller de ilişki ağının anlaşılmasını, yorumlanmasını olanaklı kılmaktadır. Latour'a ${ }^{71}$ göre miyopik bakış; ilişki ağlarının anlaşılmasında ön kabullere yer vermeden aktör ve aktantların bir bir izlenmesi ve ilişkilenme alanlarının belirlenmesini içerir. Bir ilişki ağını anlamlandırabilmek içinse "miyopik" bir bakış gereklidir.

65 Tarde, 1969'dan akt. Bruno Latour, “Tarde ve Toplumsalın Sonu”, çev. Fırat Berksun, Emre Koyuncu ve P. Burcu Yalım, Tesmeralsekdiz, $2 / 3$ (2008), s.34. (erişim 27.05.2019).

66 Latour, 1999: 179'dan akt. Steffen Korsgaard, "Entrepreneurship as Translation: Understanding Entrepreneurial Opportunities through Actor-Network Theory”, Entrepreneurship \& Regional Development, 23 (2011), s.665.

67 Law, 1999'dan akt. Tutgun-Ünal, "Sosyal Medya”, s.18.

68 Seçilmişler ve Yenen, “Koruma Sorunsalına”, s.381.

69 Latour 2005’ten akt. Karakaş, “Toplumsal Hareketler”, s.77.

70 Israel Rodríguez-Giralt, "Social Movements as Actor-Networks: Prospects for a Symmetrical Approach to Doñana’s Environmentalist Protests”, Convergencia Revista de Ciencias Sociales, 56 (2011), s.21-27.

71 Latour, "Reassemblingthe", s.171-175. 


\section{Aktör İlişskilerağı Kuramının Sağlık-Hastalık Sosyolojisine Uyarlanması}

Aktör İlişkilerağı Kuramı’nın sağlık sosyolojisi alanına uygulanan kapsamlı bir şekli Kasapoğlu'nun editörlüğünde yayımlanan Madalyonun İki Yüzü: Hastalık ve Sağlık (2008) eserinde bir araya getirilmiştir. Kasapoğlu’nun ${ }^{72}$ da belirttiği gibi, hastalıklar biyopsikososyal bir yaklaşımla ve Aktör İlişkilerağı Kuramı’yla ele alındığında: aktör (actor)-hasta, aktant (actant)-hastalık, dönüşüm (translation)-hastalığın bilimsel bir otorite tarafından hastaya anlayacağı dille anlatılması, bütünlük algısı (punctualization)-hastanın, vücudunun hasta kısmına odaklanarak yaşamaya başlaması, tersinemezlik (irreversibility)-hastalığın geri dönüşü olmayan bir şekilde hastanın hayatına dahil olması gibi ana noktalarla eşleştirilebilir. Bu durumun ana hatları Şekil 2'de görülmektedir.
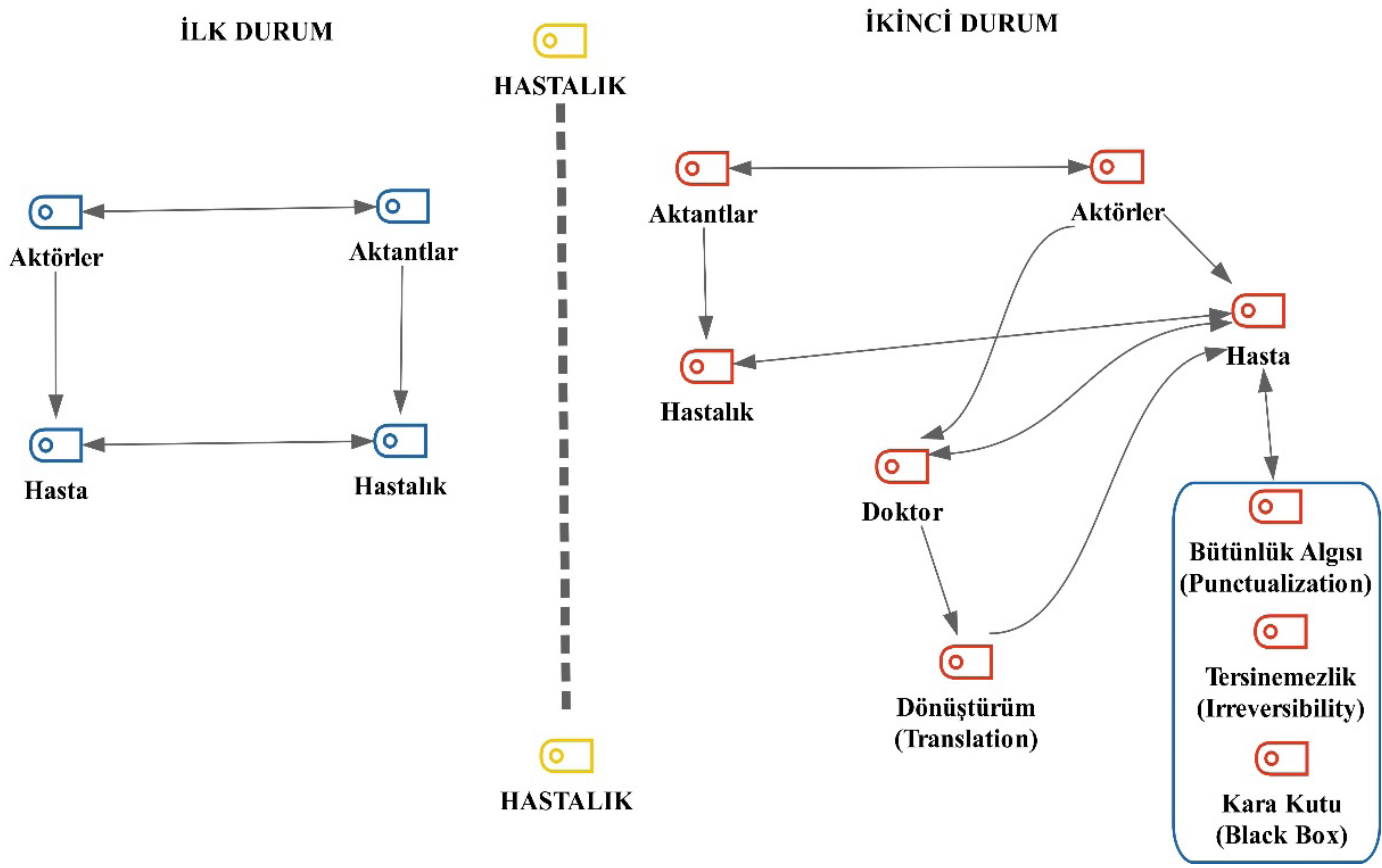

Şekil 2: Hastalık Öncesi ve Sonrasında Hastanın Etkilenme Durumu

Aynı zamanda kara kutu (black box) olarak nitelenen ilişki ağındaki karanlık bölgelerin oluşumu da önemlidir. Her ne kadar sistemin etkileşim sırasında giriş çıkışlara müsaade etmeyen bir yapısının olduğu savunulsa da etkileşim ve ilişkilerin öznelerin doğasından ve özellikle aktantlardan hariç düşünülemeyeceği açıktır. ${ }^{73}$ Bir ilişki ağ oluşurken ve etkileşim devam ederken dengeli ve düzenli bir ilişki yumağından söz etmek yerinde bir tespit değildir. Çünkü kuramın akış ve devamlı etkileşim üzerine kurulu olması denge ve düzeni imkânsız kılmaktadır.

\section{Kriminal Sosyoloji ve Merton'ın Gerilim Yaklaşımı}

Kriminal sosyoloji, suçun; psikolojik, sosyal, coğrafi, kültürel, hukuksal vd. boyutlarını sorular sorarak araştırır ve nedenlere odaklanarak ortaya kapsamlı bir açıklama 
koymayı amaçlar. Bu bağlamda sosyolojik açıklamalar, herhangi bir kriminal olayın açıklanmasında daha kapsamlı ve interdisipliner olabilmektedir. ${ }^{74}$

Gerilim (strain) olgusu, "bireylerin geleneksel araçlarla meşru bir hedefi gerçekleştirmede yaşadığı başarısızlığı veya meşru hedeflerin yine meşru yollarla elde edilmesinin bloke edilme sürecini tanımlamaktadır" ${ }^{75}$ Aynı şekilde Merton’n kuramında da suç; "ani sosyal değişme ile ortaya çıkan bir olgu değil, daha çok toplumsal yapı fenomenidir"."

Merton'ın gerilim yaklaşımına göre toplumdaki anomik durumlara karşı beş farklı tepki meydana gelir: uyum (comformity), yenilik (innovation), şekilcilik (ritualism), geri çekilme (retreatism) ve isyan (rebellion). Çalışmada kullanılan isyan durumunda, bireyler hem var olan toplumsal hedefleri hem de bu hedeflere ulaşmak için kullanılması öngörülen meşru yolları yıkarak yerine yeni amaç ve araçlar sunan bireylerdir. ${ }^{77}$ Kızmaz’ın ${ }^{78}$ çalışmasında da değindiği üzere bu tür gerilimden doğan bireysel adalet arayışları, Türkiye özelinde, öç alma ve cezalandırma şeklinde ortaya çıkarken Merton’n yaklaşımıyla uyumlu olması dikkate değerdir. Çünkü bu arayışların temelinde bireysel inisiyatif alma ve adaleti legal yollarda bulamayıp illegal yollara başvurma edimi göze çarpmaktadır.

\section{Yöntem}

$\mathrm{Bu}$ çalışma nitel bir araştırma yaklaşımıyla yapılmıştır. Yapısı gereği nitel araştırmalar, çalışılan konuyu anlamayı kolaylaştıran yorumlar ve materyalleri kullanarak dünyayı; "alan notları, mülakatlar, konuşmalar, fotoğraflar, kayıtlar ve araştırmacı günlüklerini içeren bir temsiller serisine dönüştürür" ${ }^{79}$ Burada amaç, araştırılan konunun anlam kategorilerinden hareketle ortaya konulmasıdır.

Sinemanın toplumsalı anlamada seçkin bir araç olduğu aşikardır. ${ }^{80}$ Gündüz ve Ertong Attar ${ }^{81}$, Westworld ${ }^{82}$ dizisinin sosyolojik bir okumasını yaptıkları çalışmalarında olduğu gibi, distopik bir sinematik öğenin bile çok da uzak bir geleceğe gönderme yapmadığı, aksine gündelik hayatta yer yer karşılık bulduğu düşüncesi sinemanın bilimsel araştırmalarda yol göstericiliğine bir dayanaktır. Çünkü sinematik örneklemleri konu edinen bilimsel çalışmalarda "analiz edilen şey, filmin bizatihi

74 Anthony Giddens, Sosyoloji, çev., Hüseyin Özel, İstanbul: Kırmızı Yayınları, 2012, s.838-887.

75 Zahir Kızmaz, "Kriminolojide Yeni Yönelimler: Bütünleşik (Integrated) Suç Kuramları-I”, Fırat Üniversitesi Sosyal Bilimler Dergisi, 15/2 (2005), s.353. (erişim 27.05.2019).

76 Merton 1968'den akt. Özge Cömert ve Yelda Sevim, “Çocuk ve Suç İlişkisinin Sosyolojik Suç Kuramları ile İncelenmesi”, Bitlis Eren Üniversitesi Sosyal Bilimler Enstitüsü Dergisi, 6/1 (2017), s.33-34. (erişim 27.05.2019).

77 Veysel Bozkurt, Değişen Dünyada Sosyoloji: Temeller, Kavramlar, Kurumlar, Bursa: Ekin Basım Yayın, 2011, s.183-184.

78 Zahir Kızmaz, “Şiddetin Sosyo-Kültürel Kaynakları Üzerine Sosyolojik Bir Yaklaşım”, Fırat Üniversitesi Sosyal Bilimler Dergisi, 16/2 (2006), s.254. (erişim 27.05.2019).

79 Denzin ve Lincoln, 2011: 3’ten akt. John H. Creswell, Nitel Araştırma Yöntemleri: Beş Yaklaşıma Göre Nitel Araştırma ve Araştırma Deseni, çev. Ayfer Budak ve İbrahim Budak, Ankara: Siyasal Kitabevi, 2016., s.43.

80 Diken ve Laustsen, Filmlerle Sosyoloji, s.43.

81 Ali Gündüz ve Günnur Ertong Attar, “'Her Kahramanın bir Kodu Vardır’: Westworld Dizisine Özne-İktidar-

Gözetim Üçgeninden Bakmak”, Akdeniz İnsani Bilimler Dergisi, 8/1 (2018).

82 "Westworld", son güncelleme 29 Şubat, 2020, https://www.hbo.com/westworld. 
kendisi değil; onun göndermede bulunduğu veya gizlediği örtük gerçekliktir". ${ }^{83} \mathrm{Bu}$ nedenle örneklem seçilirken, "filmler asla bir bireyin ürünü değildir" ${ }^{84}$ anlayışından hareketle, sinema eserinin toplumsala ışık tutabilecek bir ön çalışma alanı ve alegorik bir toplumsal temsil serisi olduğu düşünülmüsstür. Bu görüşü destekleyen bir röportajdaysa senarist Hakan Günday kendisini şöyle ifade etmiştir: "Yazı benim için öylesine mucizevi bir araç ki beni rahatsız etmeyen konuları anlatmanın büyük bir israf olacağını düşünüyorum". ${ }^{85}$ Reel hayattaki pek çok problemin yansımasına Günday'ın kitaplarında da rastlarız ve bu eserler tıpkı Şahsiyet gibi "ben olsam ne yapardım?” sorusunu sordurtacak kadar zihnimize işler. Çünkü herhangi bir kurgunun aslında oralarda bir yerde şu an yaşanıyor oluşunun en ufak bir ihtimali bile, kurgunun aslında distopik yönünden uzaklaşmaya neden olan bir soğuk duş etkisi yaratır. Armutçu'nun ${ }^{86}$ haberinde de olduğu gibi 28 kişinin tecavüzüne maruz kalan 13 yaşındaki bir çocuğun gündelik hayatta da karşımıza çıkıyor oluşu aslında Şahsiyet'in, gerçek hayatın izlerini taşıyan bir senaryosu olduğunu gösterir. Dizinin bu özelliğinin sosyolojik anlamda altı çizilmelidir. Çünkü Özden'in ${ }^{87}$ de belirttiği gibi sinematik öğeler, içinde doğduğu toplumun yaşamını temalarında ve karakterlerinde taşırlar.

İlişki ağlarını anlamanın temel şartı olan o ilişki ağındaki ilişkilere dahil olarak sosyolojik gözlem yapma durumu ${ }^{88}$, bu çalışmada bir dizi özelinde gerçekleştirilmiştir. Bu durum; tüm hareket, söz, jest ve mimikler gibi ilişkileri şekillendiren faktörleri tekrar tekrar inceleme firsatı verdiği için, video kayıtları üzerinde yapılan bir araştırma biçimi olarak da ele alınabilir. Hemen bu noktada eklenmelidir ki; çalışmanın konumu, ne sinemayı sosyolojiye ne de sosyolojiyi sinemaya indirgeyecek bir yerde değildir.

Problem, konu, sınırlılık ve örneklem bağlamında Şahsiyet dizisinin 12 bölümü izlenmiş ve gerekli yerler çalışmaya uygunlukları bağlamında not alınmıştır. Tekrar tekrar incelenip revize edilen notlar, kuramsal ve kavramsal çerçeve dahilinde tematik kategorilere ayrılmış ve uygunlukları derecesinde çalışmaya aktarılmıştır. Nitel içerik analizi olarak kullanılan bu teknik, araştırmacılar tarafından elde edilen gerek materyal bulguları (doküman, belge, film vb.) gerekse alan deneyimleri (gözlem, görüşme vb.) gibi birincil kaynaktan gelen üstü örtülü verilerin ardında yatan ikincil ve verilmek istenen anlamı ortaya çıkartmaya yönelik bir gayrettir. ${ }^{89}$ Ayrıca Aktör İlişkilerağ 1 Kuramı salt bir kuramdan daha çok, maddi semiyotik/materyalist semi-

83 Sertaç Ti冈mur Demir, "Dijital Aşklar: Sanallık ve Gerçeklik Arasında Bedenin, Mekânın ve İletişimin Tasarımı", TRT Akademi, 1/2 (2016), s.512. (erişim 26.05.2019).

84 Kracauer 2004'ten akt. Bülent Diken, Graeme Gilloch ve Craig Hammond, Nuri Bilge Ceylan Sineması: Türkiyeli Bir Sinemacının Küresel Hayal Gücü, çev. Ahmet Nüvit Bingöl, İstanbul: Metis Yayınları, 2018, s.15.

85 Özlem Özdemir, "Şahsiyet: İki Yalnız İnsanın Hikayesi”, 221 B Dergisi, 15 (2018), s.27.

86 "Ağlaya Ağlaya Anlattı”, erişim 26 Mayıs, 2019, http://www.hurriyet.com.tr /gundem/aglaya-aglayaanlatti-155966.

87 Zafer Özden, Film Eleştirisi: Film Eleştirisinde Temel Yaklaşımlar ve Tür Film Eleştirisi, İmge Kitabevi, 2014, s.161.

88 Brown ve Capdevila, 1999'dan aktaran George Ritzer, Modern Sosyoloji Kuramları, çev., Himmet Hülür, Ankara: De Ki Basım Yayım, 2013, s.517.

89 Nuri Bilgin, Sosyal Bilimlerde İçerik Analizi: Teknikler ve Örnek Çalışmalar, Ankara: Siyasal Kitabevi, 2014, s.1-28. 
yotik ${ }^{90}$ bir yaklaşım olarak ele alınabilir, bu nedenle onu bir yöntem olarak nitelendirmek yanlış olmayacaktır. ${ }^{91}$

Merriam’ın da belirttiği üzere, "belgeler kapris yapmaz" ve "hayal dünyası geniş olan bir araştırmacı için hazır bilgi kaynağıdır" ${ }^{\prime 2}$. Çünkü belgeler çoğu zaman; dış etkenlere karşı korunan, bir karışlık harici disklerde koca oda dolusu bilgiyi içerebilen ve en önemlisi de çoğaltılabilir özellikleriyle araştırmacılara kolaylıklar sağlayan dokümanlardır. Doküman, "araştırma öncesi elde mevcut olan herhangi bir şey demektir" 94 ve bu anlamda da bilimsel çalışmalarda kullanılan sinematografik dokümanlar, reel hayatın ilişkilerini anlamamıza olanak sağlayan portatif araçlardır.

"Sanat yapıtının bir yorumunu yapmak, onu özgün bir bakış açısından yeniden betimlemeyi gerektirir" ${ }^{95}$ Veri analizi de araştırmacının örneklemden elde ettiği verileri bulgulara dönüştürme ve anlayıp yorumlama sürecidir. Veri analizinin uygulanma amacıysa araştırmadaki sorulara cevaplar bulmaktır. ${ }^{96} \mathrm{Bu}$ cevaplar kategori ya da temalara ayrılarak cevaplanabilmektedir ve unutulmamalıdır ki; "bütün veri analizleri öncelikli olarak tümevarımsal ve karşılaştırmalıdır". ${ }^{97} \mathrm{Bu}$ amaç doğrultusunda elde edilen içerik analizi bulgularının anlamları, nitel araştırmanın doğasına uygun olarak bölümlere ve parçalara ayrılmış tıpkı "bir soğanın katlarını ayırır gibi”98 önce çlkarılıp sonra tekrar birleştirilebilir hale getirilmiştir. Tüm bu özellikleriyle betimsel bir çalışma ortaya konulmuştur. Ayrıca MAXQDA Analytics Pro 2020 paket programı yardımıyla da çalışmada bulunan 3 şekil oluşturulmuştur. Buradaki amaç, çalışmada kullanılan ve elde edilen verilerin nitel araştırmanın özüne uygun bir şekilde yeniden ve daha anlaşılır bir şekilde görselleştirilerek ortaya konmasıdır.

Araştırmanın sınırlılıklarını; Aktör İlişkilerağı Kuramı, biyopsikososyal sağlık sosyolojisi yaklaşımı, Merton'ın gerilim yaklaşımı, yöntem açısından içerik analizi ve örneklem olarak Şahsiyet dizisinin 12 bölümü oluşturmaktadır. Ayrıca örneklem bağlamında, dizideki tüm etkileşimler ve ilişki ağları incelenmemiş olup dizinin üretim sürecindeki kamera, oyuncular, çekim süreci gibi reel faktörler de araştırmanın sınırları dışında tutulmuştur.

\section{Bulgular ve Tartışma}

Çalışma bağlamında Alzheimer hastalığına değinmek yararlı olacaktır. "Alzheimer hastalığı, Alzheimer demansı sendromu ile sonuçlanan ilerleyici nörodejeneratif bir

90 Odabaş, Sürdürülebilir Afet.

91 Hacer Ansal, Mehmet Ekinci, Duygu Kaşdoğan, “Bilim, Teknoloji ve Toplum Çalışmalarına Bir Giriş”, Toplum ve Bilim, 144 (2018).

92 Sharan B. Merriam, Nitel Araştırma: Desen ve Uygulama İçin Bir Rehber, çev., ed. Selahattin Turan, Ankara: Nobel Akademik Yayıncılık, 2013, s.131.

93 Merriam, Nitel Araştırma, s.131.

94 Merriam, Nitel Araștırma, s.131.

95 Lale Kabadayı, Film Eleştirisi: Kuramsal Çerçeve ve Sinemamızdan Örnek Çözümlemeler, İstanbul: Ayrıntı Yayınları, 2018, s.19.

96 Merriam, Nitel Araştırma, s.161-162.

97 Merriam, Nitel Araştırma, s.167-168.

98 Creswell, Nitel Araştırma, s.194-195. 
bozukluktur".99 Tam tedavisi olmayan bu hastalık, en sık görülen (\%50-70) demans/ bunama nedenidir. ${ }^{100}$ Tam olarak sebebi bilinememektedir. Alzheimer'ın üç ana evresi vardır. Erken evrede, unutkanlık, tanıdığı yerlerde kaybolma, çabuk sinirlenme gibi sorunlar yaşanır. Orta evredeyse unutkanlık durumu ilerler ve erken evredeki bozukluklar daha da yoğunlaşır. Geç evrede hasta, tamamen bağımlıdır ve geçmişe yönelik sadece anı kırıntıları hatırlar. ${ }^{101}$

Şahsiyet dizisinde de Agah, Alzheimer başlangıcı teşhisinin konmasıyla bambaşka birine dönüşür. $\mathrm{Bu}$ değişim sürecinde Agah’n ilişki ağı üç ana başlık altında incelenmiştir. Bunlar: a) toplumsal ve kurumsal çatlaklar, b) hastalığın farkına varılması ve hastalığın kabul edilip hayatın ilişki ağının değişimi ve c) değişen ilişki ağıyla birlikte aktörde, bambaşka edimselliklerin ortaya çıkışı şeklinde özetlenebilir. Genel anlamda münzevi bir yaşam tarzından bir hastalık durumuyla birlikte farklı etmenlerin de etkisiyle cinayete yönelen Agah’n yaşamını konu alan bu çalışma, dar bir ilişki ağından (tek başına yaşayan emekli memur) geniş bir ilişki ağına (ülke çapında aranan bir seri katil) ve tekrar dar bir ilişki ağına (bakımevine yerleşmesi) uzanan dönüşümün bir analizidir.

\section{Hınca ${ }^{102}$ Yol Açan Ayrımlar: Toplumsal ve Kurumsal Çatlaklar}

Bu başlık altında Agah’in cinayet motivasyonuna zemin hazırlayan ve onu toplumsal anlamda rahatsız eden birtakım etkenler ortaya konulacaktır. ANT penceresinden konuya baktığımızda; toplumsal olayların birey üzerinde yarattığı duygusal etkinin (vicdani sorumluluk ya da etik değerlerin ihlali gibi) bir aktanta dönüşüp öznelerin ilişki ağına farklı aktant ve aktörleri dahil edebilecek düzeye gelmesi açısından değerlidir. Çünkü vicdani bir duygulanımsallı̆̆ın Agah’ın ilişki ağına, hastalık teşhisinden sonraki "nasıl olsa unutacağım" fikri kadar etki ettiği ve ağı dönüştürdüğü ortadadır.

Agah’a ulaştırılan Reyhan’’n günlüğündeki anlatıda ağır ceza hâkimi, öğretmen, hırsız, polis, yoksul, zengin, okumuş, cahil olarak tanımlanan 53 kişinin, 12 yaşındaki Reyhan’a iki sene boyunca tecavüz ettiği yazar (B12, 37:05) ${ }^{103}$. Reyhan’ın erkek arkadaşının bir ağabeyi olarak karşımıza çıkan Cemil'in, kendini okutanlara Reyhan’ı "hediye" ettiğini yine günlükten öğreniriz (B12, 42:06). Bu anlamda Reyhan’n günlüğü bir aktant ve tecavüzcüler de ilişki ağının birer aktörüdür. Günlükten alınan bazı cümleler, maktullerin alınlarına cinayet sonrasında Agahin dizi boyunca verdiği mesajları olarak yapıştırılmıştır. Agah’n, Nevrảnın cinsel istismar olayını ha-

99 Richard Clark, "Hastalığa Genel Bakış-Alzheimer Hastalı̆̆ı", çev., Koray Karabekiroğlu, Aytül Karabekiroğlu ve Beril Taşkın, Bestmedicine Alzheimer Hastalğğ, haz., Susan Benbow, İstanbul: And Yayıncllık, 2005, s.1.

100 Kaynak Selekler, “Alois Alzheimer ve Alzheimer Hastalığı”, Türk Geriatri Dergisi, 13 (2010), s.9-14. (erişim 26.05.2019).

101 Gözde Dalan Polat, “Alzheimer Hastalığının Antropolojisi”, Yüksek Lisans Tezi, Yeditepe Üniversitesi, 2013, s.27-29.

102 Buradaki "hınç" kelimesiyle, İngilizce'deki "grudge" anlamı kastedilmiştir. Grudge: "Geçmişte yapmış oldukları bir şey yüzünden birisine karşı hoşnutsuzluk veya öfke duyma hissi” (“Grudge”, erişim 26 Mayıs, 2019. https://dictionary.cambridge.org/us/dictionary/turkish/grudge_1.2019).

103 Parantez içlerindeki "B7, 36:35" ya da "B12, 01:02:34" gibi ifadeler ilgili sahnenin dizinin neresinde geçtiğini belirtmektedir. Örneğin "B12, 01:02:34" sahnesi, dizinin 12. bölümünde 1. saat 2. dakika 34. saniyesinde geçtiğini gösterir. Süreler, Puhu TV’nin orijinal Şahsiyet dizisi videoları üzerinden tespit edilmiştir. 
tırlaması için bıraktığı bu mesajlarda Nevrảnın ağa dahil olması için çağırma görevi üstlendiğinden aktant olarak nitelendirilebilirler.

Dizide bir diğer aktant da Agah’ın torunu Deva’nın, bazı cinayetlerini kedi kostümü giyerek işleyen seri katile ilgi duyan hayranlar için kurduğu web sitesidir. Sitenin adı ve katile taktıkları lakap Köpek Öldüren'dir. Deva, siteye ve katile verilen bu ismin; doğanın kanuna aykırı olduğunu ve zayıfın, güçsüzün, sessizin başkaldırısına örnek teşkil ettiğini söyler. Bu web sitesi üzerinden "Köpek Öldüren'in Kimi Öldürmesini İstersiniz?” şeklinde bir forum kurmuşlardır. Afşin, web sitesindeki durumu şöyle tarif eder: "Ulan kaç kişi yazmış böyle? İnsanlar hayatları boyunca bu anı beklemişler sanki ya. Hani biri sorsa da biz de yazsak diye" (B8, 01:28). Listedeyse; parkta çekirdek çitleyip kabuklarını yere atanlar, trafikte sürekli korna çalanlar, herhangi bir kuyrukta arkada çok yakın bekleyenler yer almaktadır. Böylesi durumlardan rahatsızlık duyan herkes, Köpek Öldüren'i alternatif bir adalet sağlayıcı ya da kendileri suya sabuna dokunmadan hınçlarını alacak bir "tetikçi” olarak görür. Bu noktada web sitesi de bir aktanta dönüşmüş ve ilişki ağındaki etkileşimin bir parçası olmuştur. Köpek Öldüren karakterinin cinayetlerini savunanların, ANT'nin yetki aktarma ve dahil etme (delegates and inscription) kavramiyla uygun olduğu görülmektedir. Çünkü anonim bir karakter olarak Köpek Öldüren, toplumdaki hıncın her bireyden ayrı ayrı toplanarak tek bir “tetikçi”ye yüklenen rolünü bize gösterir. Latour’a göre ${ }^{104}$ aktör ağın uzunluğu veya genişlemesi etkinliği, gücü ve gerçekliğiyle ilişkilendirilebilir. $\mathrm{Bu}$ nedenle Deva ve arkadaşlarının öncülüğünde kurulan bu sitenin zinciri genişlettiği söylenebilir.

\section{Biyolojik Bir Yin-Yang ${ }^{105}$ : Insan}

Agah çok sevdiği kedisi Münir Bey’i ölmüş halde bulur (B1, 09:29). Bu noktadan sonra Agah’ın hayatı değişmeye başlayacaktır. Kedisini, ölüm nedenini anlamak için veterinere götürür. Ölüm nedeni akut böbrek yetmezliği ve susuzluktur (B1, 10:02). Kedisinin bakımını aksatan Agah’n unutkanlık serüveni bu acı tecrübeyle yavaş yavaş ortaya çıkmaya başlar. Münir Bey, bu sahnede bir aktant olarak karşımıza çıkar ve onun ölümü ilişki ağının şekillenme serüveninin ilk adımlarındandır. Bir aktantla etkileşimi sonucunda hayatı değişen Agah, ağdaki mevcut konumunu değiştirmiş, baş aktör olarak yeni ağların da oluşmasını sağlamıştır. Bu, Çetin'in ${ }^{106}$ sosyal hayat üzerinde insanlar ve evcil hayvanların etkileşiminin önemine yaptığı vurguyla da tutarlıdır.

Agah tedavi için doktora gider ve hastalığı bir türlü kabullenmez. Testi tekrar yap-

104 1977: 122-123’ten akt. Çağatay Topal, “Meta Fetişizmi: Latourcu Bir Okuma Denemesi”, Mediterranean Journal of Humanities, 7/2 (2017), s.425. (erişim 26.05.2019).

105 Yin-Yang, "Taoculukta ve Çin halk dininde, uzlaşmaz bir şekilde çelişkili; ama birbirini tamamlayan temel ilkeler döngüsüdür" [René Guénon, "Siyah ve Beyaz (Sembolizmi)", çev., Sadık Kılıç, Atatürk Üniversitesi İlahiyat Fakültesi Dergisi, 23 (2005): 218-219]. Bu öğretiye göre her şey iki kutupludur ve birbirine karşıttır, kutuplar karşıtını muhakkak kendi içinde barındırır, karşılıklı olarak bir diğerine dönüşebilirler ("Yin-Yang”, son güncelleme 26 Mayıs, 2019, https:// tr.wikipedia.org/wiki/Yin_ile_yang). Bu başlıklaysa insanın içinde hem iyiliği hem de kötülüğü barındırabildiği gibi hem hastalık hem de sağlığın toplumsal eylemdeki önemi kastedilmiştir. 106 Ebru Çetin, “Tüketim Toplumunda Evcil Hayvanların Sahiplenilmesi: Sosyolojik Bir Analiz", Sosyoloji Araştırmaları Dergisi, 20/2 (2017) s.92. (erişim 26.05.2019). 
tırmak ister (B1, 14:30). Doktor durumun zor olduğunu bildiğini söyleyerek teşhisin kesinliğinden emindir: Alzheimer başlangıcı (B1, 14:54). Latour ve Woolgar'ın ${ }^{107}$ da belirttiği üzere bilim insanının laboratuvar ya da bilimsel literatür ortamındaki bilgiyi gündelik dile çevirme için bir yazma işlemleri zinciri (a chain of writing operations) oluşturduğu söylenebilir. Bu sahnede de doktor, tahlil sonuçlarını Agah’in anlayacağı şekle dönüştürmüştür. Kısaca Agah, zamanla her şeyi unutacaktır ve ellerinden gelen tek şeyse bu süreci olabildiğince geciktirmektir. Hem hastalığ hem de sağlığı aynı anda bünyesinde barındıran Agah, literatürdeki yarı sağlıklı insan (ill health) durumunun bir örneğidir. Gerek başlıktaki Yin-Yang metaforu gerekse yarı sağlıklılık durumu ANT literatüründeki melezlik (hybrid) durumunun bir yansımasıdır. Çünkü Agah, hastalığıyla canlı ve canlı olmayanların birlikteliğini yansıtan hybrid/melez bir bedendir. Ayrıca Agah’ın kedisinin ölümüne neden olan unutkanlığ1 getiren rahatsızlığı (illness), burada doktorun Alzheimer başlangıcı teşhisiyle birlikte hastalığa (disease) dönüşmüş olur. ANT literatüründeki tersinemezlik ilkesiyse tam tedavisi ya da geri dönüşü olmayan Alzheimer hastalığında ortaya çıkmıştır. Doktoru Agah'la konuşurken hastalık belirtisi ve ilaçların yan etkisi olarak ani öfke patlamaları olabileceğinden bahseder. ANT literatüründe kara kutu (black box) olarak adlandırılan sürece benzer şekildeki bu durum, Agah'ın doktor randevularında hastalığı hakkında öğrendikleri ve kendi hayatında tecrübe ettikleriyle sürekli aydınlanan bir süreci temsil etmektedir. Kayış'ın ${ }^{108}$ alan çalışmasındaki aktörler gibi Agah da sürekli kara kutuyu kurcalayarak ve uzmanlarca ikna edilmeyi bekleyerek ilişki ağına gittikçe dahil olmaktadır.

Yemekli bir geceye arkadaşı Mümtaz’nn ısrarıyla katılan Agah, huysuzluk ederek içki içenlerle dalga geçer. "Sabah hiçbir şey hatırlamayacaklar ne halt ederlerse etsinler" diyerek sesli düşünürken; “Tabii ya, ben her şeyi unutacağım. Hiçbir şey hatırlamayacağım ki!” fikrine ulaşır (B1, 32:50). Agah, yeni bir ilişki ağının fitilini zihninde ateşlemiştir ve burada, hastalığı olan Alzheimer bir aktanta dönüşür. Düşünümsellik, bireyin yapıp etmeleri üzerine tutarlı bir şekilde düşünmesi şeklinde açıklanır. ${ }^{109}$ Agah da yeni ilişki ağının şekillenmesindeki dönüşüm (translation) işleminin ilk adımı olan problemleştirme adımını kendini merkeze alarak düşünümsel (reflexive) bir şekilde atmış olur.

Agah ve sevgilisi Nükhet'in gittiği tiyatro oyununda şu sözler geçer: "Vicdan denen şey bağırsak gibidir. Sen uyurken de çalışır” (B4, 54:04). Bu sahnede Agah, tiyatronun ortasında dayanamayarak dişarı çıkar. Odabaş ${ }^{110}$ ile Odabaş ve Ertong'un ${ }^{111}$ çalışmalarındaki ilişki ağını şekillendiren kuraklık, deprem, tsunami gibi afet durumları, Agah’ın "unutma” korkusuyla eşleştirilebilir. Çünkü unutmak, insan zihninin yaşayabileceği en büyük çöküşlerden birisidir ve bu durum dizide, geri dönüşü olmayan/tersinemez (irreversibility) bir afet gibi, insanın/aktörün kontrolünde

107 Latour, Bruno ve Stewe Woolgar, Laboratory Life: The Construction of Scientific Facts, Princeton: Princeton University Press, 1986, s.71.

108 Kayış, “Aktör İlişkilerağı”, s.175.

109 Anthony Giddens, Modernliğin Sonuçları, çev. Ersin Kuşdil, İstanbul: Ayrıntı Yayınları, 2016, s.42.

110 Odabaş, Sürdürülebilir Afet.

111 Odabaş ve Ertong, "Social Effects". 
değildir. Ayrıca Agah unutursa vicdani ideali olan cinayetleri işleyemeyecektir. Bu noktada, daha önce göz önünde bulundurulmamış insan olmayan bir unsurun yani hastalık aktantının, A durumundan B durumuna geçişe köprü olup bireyin edimlerinin ciddiye alınmasını sağlayacak etki gücü karşımıza çıkmaktadır. ${ }^{112}$

\section{Bireysel Adalet Arayışı: Vigilante ${ }^{113}$}

Bireysel adalet arayışında olan Agah, daha önce çalıştığı Ardıçhan Adliyesỉnin adli emanet deposu arşivinin anahtarını, depo olarak kullandığı alt katındaki dairesinden alarak ilgili dosyaları almaya gider. Dosyaları alıp adliyeyi ateşe veren Agah, kendi adaletini kuracaktır (B1, 37:20). Walter Benjamin'in ${ }^{114}$ de belirttiği gibi: "Şiddet ve ahlak arasındaki ilişkinin çerçevesi, hukuk ve adalet kavramları tarafından çizilir". Tıpkı Seçilmişler' in ${ }^{115}$ çalışmasında da olduğu gibi yasalar, resmi evraklar ve planlar, bundan sonra Agah'ın edimlerini şekillendirecek birer aktant olarak karşımıza çıkacaktır. Dosya çuvallarını arabasının bagajına koyduğu sahnede, arka planda hukuk kurumunun bir uzantısı olan arşiv deposunun yanışı, vigilante karakterimizin işe koyulduğunun bir göstergesidir. Buradan sonra yeni bir ilişki ağına dahil olan Agah, evindeki münzevi yaşamından ülke gündeminde konuşulan bir seri katil kimliğine bürünür. Çilingiroğlu'nun ${ }^{116}$ çalışmasında belirttiği gibi ilişki ağlarının konjonktüre göre şekillenip değiştiği gerçeği bu dönüşüm aşamasında da karşımıza çıkar. Çünkü Agah, 1996 yılındaki cinsel istismar olayına etki edememişken, 2018 yılında o ilişki ağını dönüştürüp şekillendiren baş aktör konumuna gelmiştir. Dönüşüm (translation) işleminin dahil olma safhasına geçtiği görülen Agah, artık hastalığı kabul etmiş ve yeni ilişki ağlarına dahil olmaya başlamıştır. Ayrıca hastalık durumu ve Agah’ın edimsel tercihleri ANT'nin yetki aktarma ve dahil etme (delegates and inscription) terimiyle açıklanabilir. Çünkü Agah, gerek hukuk kurumuna gerekse de güvenlik kurumuna etki eden bir ilişki ağını şekillendirmiştir. Dönüştürüm işleminin son adımı olan ittifakların mobilizasyonunu da farklı aktör ve aktantlara ilişki ağları içinde görevler atfederek tamamlamıştır. Çünkü baba, dede, hasta, sevgili ve katil gibi roller üstlendiği farklı ilişki ağlarını değiştirip dönüştürmektedir. Kurduğu ittifakın bir diğer yansıması da Köpek Öldüren web sitesindeki takipçileridir. Onları da harekete geçirmeyi başarmıştır.

\section{Sonuç ve Öneriler}

Bir vaka analizi gibi sosyolog, film anlatısını sosyal bilimler kuramlarından yararlanarak analiz edebilir, pek çok farklı alanda kendisine bu ilişkileri ve pratikleri takip

112 Karakaş. “Toplumsal Hareketler”, s.75.

113 Özellikle polis gibi resmi örgütlerin suçu kontrol edemedikleri düşüncesinden hareketle suçu önlemek için gayri resmi olarak, suç işleyen birini yakalamak ya da cezalandırmak için harekete geçen kişi ya da gruplardır ("Vigilante", erişim 28 Mayıs, 2019, https:/dictionary.cambridge. org/tr/s\%C3\%B6zl\%C3\%BCk/ingilizce/ vigilante).

114 Walter Benjamin, “Şiddetin Eleştirisi Üzerine”, Şiddetin Eleştirisi Üzerine, der. ve çev., Aykut Çelebi,

İstanbul: Metis Yayınları, 2010, s.19.

115 Töre Seçilmişler, “Koruma Öncelikli Alanlarda Aktör Ağın Çözümlenmesi ve Betimlenmesi: İstanbul Tarihi Yarımada Örneği”, Yüksek Lisans Tezi, Yıldız Teknik Üniversitesi, 2010, s.104.

116 Çiler Çilingiroğlu, “Arkeolojide İlişkisel ve Simetrik Yönelimler: Bir Giriş”, TAG-Türkiye Toplantısı Bildirileri 2, haz., Güneş Duru, Kenan Eren ve Elif Koparal, İstanbul: Ege Yayınları, 2017, s.58-59. 
ederek bu ağı haritalandırma ${ }^{117}$ görevini biçebilir. Sağlık ve hastalık sosyolojisi bağlamında düşünüldüğündeyse, bir film üzerinden bu analizi yapmak bu vakaya daha yakından bakmak için bir hasta dosyası incelemek, yönetmenin kullandığı farklı kareleriyse, olayın farklı açılarını deneyimleyen insanları gözlemleme olarak düşünülebilir. Bu bakış açısı ANT’nin etnometodolojik kökleriyle ${ }^{118}$ de uyumludur.

Agah’n önce kısıtlı bir sosyal çevreyle emekli hayatı sürdüğü izlenimi ediniriz. Sonraysa ihmal sonucu kedisinin ölmesiyle birlikte hastalık durumunun ilk belirtilerini görürüz. Doktor, Alzheimer başlangıcı teşhisiyle birlikte Agahı̉n yıllardır zihninde taşıdığı bir "vicdani ideal/intikam" durumunun toplumsal hayatta karşılık bulmasının yolunu açar. Ülke çapında bir ilişki ağına hitap eden seri cinayetler, Agah’ın ilişki ağının çeşitlenip farklılaşmasına neden olmuştur. Daha sonraysa hastalığının elverdiği kadar intikamını alan Agah, bakımevinde kısıtlı bir ilişki ağına geri dönmüştür. Tüm bu ilişki ağı dönüşümünü Agah’n Reyhan’ın günlüğüyle (aktant) kurduğu ilişki, Alzheimer hastalığının teşhisi (aktant) ve Agah’n harekete geçmesi (aktör) şeklinde üç ana noktaya indirgeyebiliriz.

Materyal semiyotik bir analizi işlevsel kılan, buradan çeşitlenen ilişki ağında Agah’̉n baba, dede, sevgili, katil, hasta gibi rollerde farklı ilişkileri insan ve insan olmayan unsurlarla yürüttüğünü görmemizi kolaylaştırmasıdır. Vigilante karakterler sinemada yaygın olarak görülse de bunun bir hastalıkla ortaya çıkması ve işlenen suç motivasyonunun bu hastalığın getirdiği dönüşümden kaynaklanması araştırmacıların bu deneyimi ANT üzerinden okumasının başlıca nedenidir. Agah’ın, unutmayı bekleyerek eve kapanmak yerine birçok ilişki ağını etkilediği, yasal olmayan ve anonim bir şekilde unutmaktan korkarak geçmişin intikamını aldığı görülmektedir. Dizi boyunca kadraja yansıyan toplamda 12 cinayet işleyen Agah, hedeflerini kimi zaman ölüme terk etmiş, kimi zaman da hedeflerin kendini asmasına yardım etmiştir. Tabanca, yastık, bomba gibi silah nitelikli aletler Agah’n cinayet işlerken kullandığı nesnelerdir. Hukukla girdiği ilişkide sorun yaşayan Agah’n tüm ilişki ağı, hastalığın da bu ağa dahil olmasıyla dönüşmüştür. Dizideki aktör ve aktantlar genel itibarıyla Şekil 3’teki gibi bir ilişki yumağını oluşturmuştur.

117 Karakaş, “Toplumsal Hareketler”.

118 Allan McDougall vd., "Beyond the Realist Turn: A Socio®Material Analysis of Heart Failure Self $\bigotimes$ Care", Sociology of Health \& Illness, 40/1 (2018): s.20. (erişim 27.05.2019). 


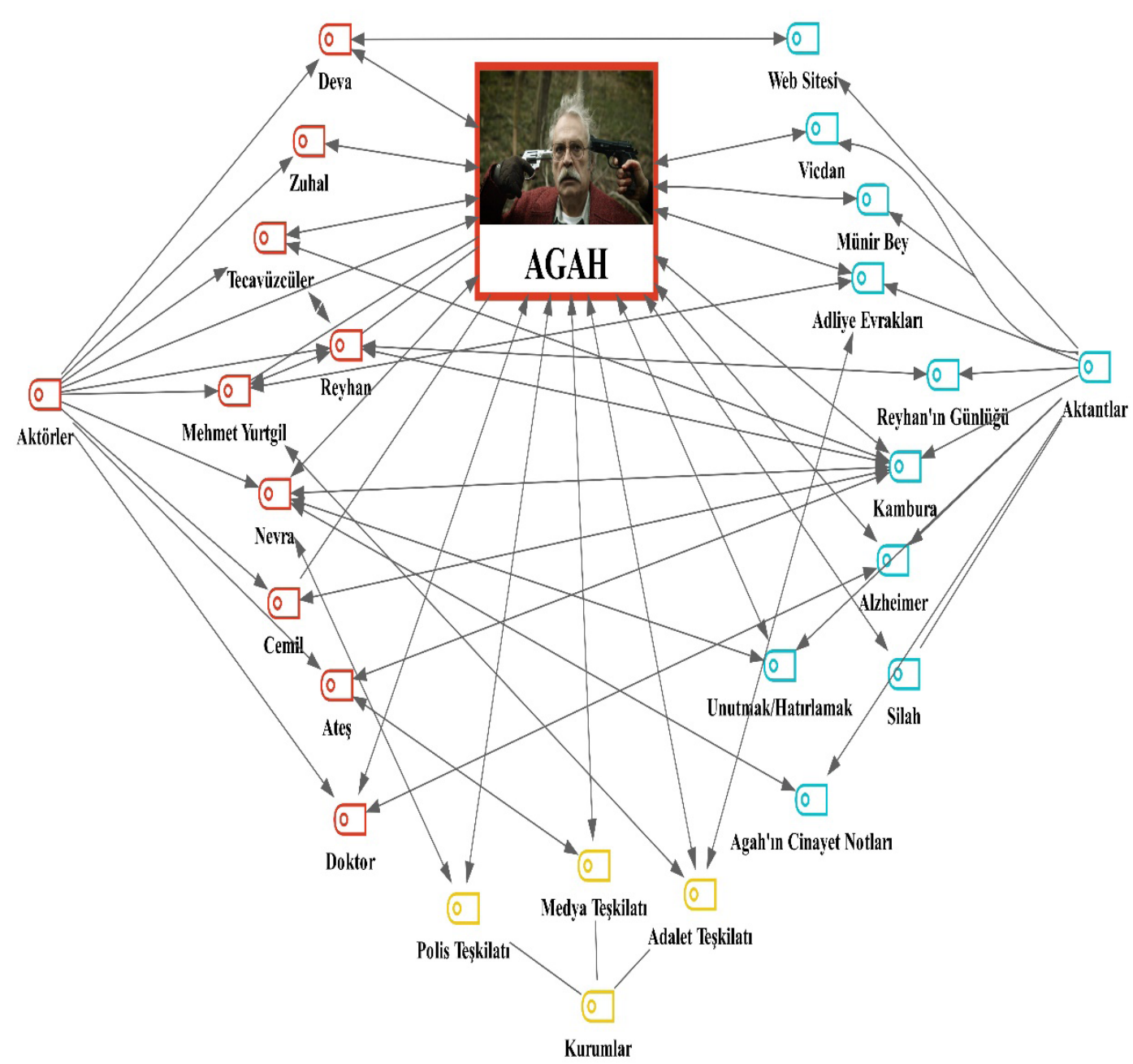

\section{Şekil 3: Hastalık Sonrası Agahı̀n İlişki Ağı}

Şahsiyet her şeyden önce bir toplumsal eleştiridir. Bu diziyi, resmin geneline bakıp olay örgüsünden bağımsız düşündüğümüzdeyse; toplumdaki ve kurumlardaki çatlakların çok büyük kırıklara sebep olabileceği, bireysel adalet arayışlarının toplumlarda taraftar bulabileceği, haksızlığa uğrayanların hakkının resmi yollarca korunup gözetilmesi mecburiyeti gözler önüne serilmektedir. Mollaer’in, Milan Kundera’dan aktardığı gibi: “İktidara karşı mücadele belleğin unutuşa karşı mücadelesi" ${ }^{119}$ olmuş ve Şahsiyet aslında Türkiye’nin pek çok toplumsal sorununa değinerek bir alegori oluşturmuştur. Toplumsal hafızadaki istismar gibi şiddet olaylarını hatırlamayı Nevra karakterinde ve bu olayların üzerini örtmeyi de Cemil karakterinde bir Türkiye alegorisi olarak görebiliriz.

Zizek'in ${ }^{120}$ belirttiği üzere her ne kadar "filmler yalan söylerken bile toplumsal yapımızın canevindeki yalanı" anlatsalar da Özden'inn ${ }^{121}$ altını çizdiği bir diğer nokta

119 "Bir Türkiye Alegorisi: Şahsiyet Dizisi Üzerine”.

120 Slavoj Zizek, “Sunuş: Toplumsalın Kalbindeki Film”, Filmlerle Sosyoloji, yaz. Bülent Diken \& Carsten B.

Laustsen, çev. Sona Ertekin, İstanbul: Metis Yayınları, 2016, s.15.

121 Zafer Özden, Film Eleștirisi: Film Eleştirisinde Temel Yaklaşımlar ve Tür Film Eleştirisi, İmge Kitabevi, 2014, 
önemlidir: Sinematik öğelerin içinde yer alan kültürel kodlar, problemler ve çözüm yolları her ne kadar kurgu bir yapı sergilese de bu sinematik öğelerden etkilenen bireylere gerçek hayatta yol gösterici düşünce, tutum ve davranış kalıpları empoze edebileceğinden, dizinin illegal yollardan bireysel adalet arayışının tehlikeli sularında yüzdüğü söylenebilir.

Şahsiyet ve benzeri eserlerin sosyolojik, kriminolojik, psikolojik, felsefi, hukuki, adli ve etik gibi pek çok kuramsal temelle ele alınması önerilmektedir. Şahsiyet, Erbalaban Gürbüz'ün ${ }^{122}$ çalışmasındaki gibi toplumsal cinsiyet perspektifinden, Doyuran'ın ${ }^{123}$ çalışmasında olduğu gibi eleştirel söylem çözümlemesi yapılarak ya da IMDb'de gelmiş geçmiş en iyi 250 dizi listesine girmesi sebebiyle Sayar ve Sayar'ın ${ }^{124}$ çalışmasındaki gibi Gündem Belirleme Kuramı'ndan hareketle de çalışılabilecek bir dizidir. Bununla birlikte Evlioğlu’nun ${ }^{125}$ ve Yuvayapan'ın ${ }^{126}$ çalışmalarında olduğu gibi; medya, temsil, ideoloji, suç ve ceza gibi alt başlıkların hepsi teker teker ya da şemsiye bir çalışmayla bir araya getirilebilir.

\section{Teşekkürr}

Kıymetli yorumları için Prof. Dr. Ayşe AZMAN, Prof. Dr. Yaşar ERJEM ve Doç. Dr. Zuhal Yonca ODABAŞ’a teşekkür ederiz.

\section{Kaynakça}

Adak, Nurşen. “Sağlık Sosyolojisinin Temel Kavramları”. Sağlık Sosyolojisi. Mevlüt Özben. Erzurum: Atatürk Üniversitesi Açık Öğretim Fakültesi Yayınları, 2016.

Ansal, Hacer, Mehmet Ekinci ve Duygu Kaşdoğan. "Bilim, Teknoloji ve Toplum Çalışmaları'na Bir Giriş”. Toplum ve Bilim. 144 (2018): 9-38.

Armutçu, Emel. “Ağlaya Ağlaya Anlattı”. Erişim 26 Mayıs, 2019. http://www.hurriyet. com.tr/gundem/aglaya-aglaya-anlatti-155966.

Atay, Tayfun. Erişim 15 Aralık, 2019. "Ya Alzheimer Ya Cinayet: Bir Şaheserdir Şahsiyet!”, https://t24.com.tr/yazarlar/tayfun-atay-pazar/ya-alzheimer-ya-cinayet-bir-saheserdir-sahsiyet,24668.

Atay, Tayfun. Erişim 26 Mayıs, 2019. “Unutabilmenin 'Vicdani-Cinai’ Ferahlığı!”,http://www.cumhuriyet.com.tr/koseyazisi/944765/Unutabilmenin__vicdani-cinai_ferahligi_html.

“Ayaklı Gazete TV Yıldızları”. Erişim 26 Mayıs, 2019. http://www.ayakligazete.com/

\section{s. 160}

122 Nilay Özge Erbalaban Gürbüz, "Korkuyorum Anne’de Hegemonik Erkekliğin Yapı Sökümü”, Ankara Üniversitesi İlef Dergisi, 3/2 (2016).

123 Levent Doyuran, "Medyatik Bir Çalışma Alanı Olarak Eleştirel Söylem Çözümlemesi (Televizyon Dizileri Örneğinde)”, Erciyes İletişim Dergisi, 5:4 (2018).

124 Tahsin Eren Sayar ve Banu Sayar, "Black Mirror Dizisi 'The National Anthem' Bölümü’nün Gündem Belirleme Kuramı Üzerinden İncelenmesi”, Stratejik ve Sosyal Araştırmalar Dergisi. $2 / 1$ (2018). (erişim 26.05.2019). 125 Eda Evlioğlu, “Televizyon Dizilerinde Suç ve Cezanın Temsili: Karadayı Dizisi”, Yüksek Lisans Tezi, İstanbul Üniversitesi, 2016.

126 Emel Yuvayapan, “Sinemada Suç ve Ceza-Modern Toplumlarda Adalet Arayışının Sinemada Temsili”, Yüksek Lisans Tezi. Dokuz Eylül Üniversitesi, 2006. 
ayakli-gazete-yilin-enleri-belli-oldu-2/.

Bayar, Armoni. "Woman Representation in Turkish Detective Series: Şahsiyet", International Perspectives on Feminism and Sexism in the Film Industry. Gülşah Sarı ve Derya Çetin. ABD: IGI Global, 2020.

Baydar, Salih Cenap. Erişim 27 Şubat, 2020. https://www2.karar.com/yazarlar/salih-cenap-baydar/sahsiyet-12563.

Benjamin, Walter. “Şiddetin Eleştirisi Üzerine”. Şiddetin Eleştirisi Üzerine. Der. ve çev., Aykut Çelebi. İstanbul: Metis Yayınları, 2010.

Bilgin, Burcu. "Şahsiyet: Dizi Finali Bize Neler Anlattı?". Erişim 26 Mayıs, 2019. $\mathrm{http} / / /$ sinekafe.com/sahsiyet-dizi-finali-bize-neler-anlatti/.

Bilgin, Nuri. Sosyal Bilimlerde İçerik Analizi: Teknikler ve Örnek Çalışmalar. Ankara: Siyasal Kitabevi, 2014.

Bozkurt, Veysel. Değișen Dünyada Sosyoloji: Temeller, Kavramlar, Kurumlar. Bursa: Ekin Basım Yayın, 2011.

Cambridge Dictionary. "Grudge”. Erişim 26 Mayıs, 2019. https://dictionary.cambridge.org/us/dictionary/turkish/grudge_1.

Cambridge Dictionary. "Vigilante”. Erişim 26 Mayıs, 2019. https://dictionary.cambridge.org/tr/s\%C3\%B6zl\%C3\%BCk/ingilizce/vigilante.

Cirhinlioğlu, Zafer. Sağlk Sosyolojisi. Ankara: Nobel Akademik Yayıncılık, 2001.

Clark, Richard. "Hastalığa Genel Bakış-Alzheimer Hastalığı”. Çev. Koray Karabekiroğlu, Aytül Karabekiroğlu ve Beril Taşkın. Haz., Susan Benbow. Bestmedicine Alzheimer Hastalı̆ğ. İstanbul: And Yayıncllık, 2005.

Cömert, Özge ve Yelda Sevim. "Çocuk ve Suç İlişkisinin Sosyolojik Suç Kuramları ile İncelenmesi”. Bitlis Eren Üniversitesi Sosyal Bilimler Enstitüsü Dergisi. 6/1 (2017): 29-40. (erişim 26.05.2019).

Creswell, John H. Nitel Araştırma Yöntemleri: Beş Yaklaşıma Göre Nitel Araştırma ve Araştırma Deseni. Çev., Ayfer Budak ve İbrahim Budak. Ankara: Siyasal Kitabevi, 2016.

Çakır, Gencer. Erişim 15 Aralık, 2019. “Şahsiyet'in Düşündürdükleri..., http://www. ekdergi.com/sahsiyetin-dusundurdukleri/.

Çayır, Hande. Erişim 27 Şubat, 2020. “Şahsiyet Dizisinin Trans Kadını Naz’ın Sorunlu Temsili”. https://t24.com.tr/yazarlar/hande-cayir/sahsiyet-dizisinin-trans-kadini-naz-in-sorunlu-temsili-hakkinda,25106.

Çetin, Ebru. "Tüketim Toplumunda Evcil Hayvanların Sahiplenilmesi: Sosyolojik Bir Analiz". Sosyoloji Araştırmaları Dergisi. 20/2 (2019): 89-107. (erişim 26.05.2019).

Çilingiroğlu, Çiler. "Arkeolojide İlişkisel ve Simetrik Yönelimler: Bir Giriş". TAG-Türkiye Toplantısı Bildirileri 2. Haz., Güneş Duru, Kenan Eren ve Elif Koparal. İstanbul: Ege Yayınları, 2017.

Demir, Ayşe Bilge. "Şahsiyet Dizisindeki Unutma-Şahsiyet İlişkisinin Nietzscheci Görünümleri”. Erişim 26 Mayıs, 2019. https://dusunbil.com/sahsiyet-dizisindeki-unutma-sahsiyet-iliskisinin-nietzscheci-gorunumleri/.

Demir, Sertaç Ti冈mur. "Dijital Aşklar: Sanallık ve Gerçeklik Arasında Bedenin, 
Mekânın ve İletişimin Tasarımı”. TRT Akademi. 1/2 (2016): 508-527. (erişim 26.05.2019).

Diken, Bülent ve Carsten Bagge Laustsen. Filmlerle Sosyoloji. Çev., Sona Ertekin. İstanbul: Metis Yayınları, 2016.

Diken, Bülent. Graeme Gilloch ve Craig Hammond. Nuri Bilge Ceylan Sineması: Türkiyeli Bir Sinemacının Küresel Hayal Gücü. Çev., Ahmet Nüvit Bingöl. İstanbul: Metis Yayınları.

Doyuran, Levent. "Medyatik Bir Çalışma Alanı Olarak Eleştirel Söylem Çözümlemesi (Televizyon Dizileri Örneğinde)”. Erciyes İletişim Dergisi. 5:4 (2018): 301-323.

Dönmez, Dağhan. "Şahsiyet Aslında Kimdi?”. Erişim 26 Mayıs, 2019. http://www. eskimeyenkitaplar.com/sahsiyet-aslinda-kimdi/.

Ekşi Sözlük. “Şahsiyet”. Erişim 27 Şubat, 2020. https://eksisozluk.com/sahsiyet-dizi--5572069?p=1.

"Emmy Ödülleri Cumhuriyet Gazetesi”. Erişim 15 Aralık, 2019, http://www.cumhuriyet.com.tr/video/video/1704458/iste-haluk-bilginerin-odul-alirken-yaptigi-tarihi-konusma.html.

Engel, George L. "The Clinical Application of the Biopsychosocial Model”. American Journal of Psychiatry. 137 (1980): 535-544. (erişim 26.05.2019).

Engel, George L. “The Need for a New Medical Model: A Challenge for Biomedicine”. Science. 196/4286 (1977): 129-137. (erişim 26.05.2019).

Erbalaban Gürbüz, Nilay Özge. "Korkuyorum Anne'de Hegemonik Erkekliğin Yap1 Sökümü”. Ankara Üniversitesi İlef Dergisi. 3/2 (2016): 125-142.

Evlioğlu, Eda. “Televizyon Dizilerinde Suç ve Cezanın Temsili: Karadayı Dizisi”. Yüksek Lisans Tezi. İstanbul Üniversitesi, 2016.

“Galatasaray Üniversitesi EN Ödülleri”. Erişim 26 Mayıs, 2019. https://www. ntv.com.tr/sanat/sahsiyet-2018in-en-iyi-internet-dizisi-secildi,Scw3ymGd306d06-Fa9o_zQ.

Giddens, Anthony. Modernliğin Sonuçları. Çev., Ersin Kuşdil, İstanbul: Ayrıntı Yayınları, 2016.

Giddens, Anthony. Sosyoloji. Çev., Hüseyin Özel. İstanbul: Kırmızı Yayınları, 2012.

Guénon, René. "Siyah ve Beyaz (Sembolizmi)". Çev., Sadık Kılıç. Atatürk Üniversitesi İlahiyat Fakültesi Dergisi. 23 (2005): 217-222.

Gündoğmuş, Buket. “Hangi Şahsiyet Dizisi Karakterisin?”. Erişim 27 Şubat, 2020. https://onedio.com/haber/hangi-sahsiyet-dizisi-karakterisin-819481.

Gündüz, Ali ve Günnur Ertong Attar. "'Her Kahramanın Bir Kodu Vardır’: Westworld Dizisine Özne-İktidar-Gözetim Üçgeninden Bakmak”. Akdeniz İnsani Bilimler Dergisi. 8/1 (2018): 187-201. (erişim 26.05.2019).

Gündüz, Ali. "Şahsilikten Uzaktır Şahsiyet: Şahsiyet (2018) Dizisinin Düşündürdükleri Üzerine”. Pharmakon Felsefe Dergisi. 5 (2018): 39-42.

Hançer, Zuhal Yonca. “Sürdürülebilir Afet Yönetimi ve Kadın”. Doktora Tezi, Ankara Üniversitesi, 2009.

IMDb Top 250. Erişim 17 Aralık, 2019. https://www.imdb.com/chart/toptv/. 
İpşiroğlu, Zehra. “UNUTMA/Şahsiyet Dizisi Üzerine”. Erişim 26 Mayıs, 2019. https://www.dirensanat.com/2018/07/22/zehra-ipsiroglu-unutma-sahsiyet-dizisi-uzerine/.

Kabadayı, Lale. Film Eleştirisi: Kuramsal Çerçeve ve Sinemamızdan Örnek Çözümlemeler. İstanbul: Ayrıntı Yayınları, 2018.

Karakaş, Öznur. “Toplumsal Hareketler, Ağlar ve Beden”. Toplum ve Bilim. 144 (2018): 68-88.

Kasapoğlu, Aytül. “Giriş”, Madalyonun İki Yüzü: Hastalık ve Sağlık. Aytül Kasapoğlu. Ankara: Phoenix Yayınevi, 2008.

Kayaalp, Ebru ve Onur Arslan. "Belirsizliğin Bilimi: Beklenen İstanbul Depremi ve Uzmanlar Antropolojisi”. Toplum ve Bilim. 144 (2018): 124-146.

Kayış, Abdullah Cengiz. "Aktör İlişkilerağı Kuramı ve Barajlar: Yusufeli Barajı Örneği”. Karadeniz Araştırmaları. 14/56 (2017): 159-183. (erişim 26.05.2019).

Kaynak, Hande ve Denizci Nazlıgül, Merve. "Alzheimer Hastalığına Bilişsel Süreçler ve Klinik Çerçeveden Bakış: Şahsiyet Dizisinin Kritik İncelemesi”. AYNA Klinik Psikoloji Dergisi. 6 (2019): 204-222.

Kızmaz, Zahir, "Şiddetin Sosyo-Kültürel Kaynakları Üzerine Sosyolojik Bir Yaklaşım”, Fırat Üniversitesi Sosyal Bilimler Dergisi, 16/2 (2006): 247-267. (erişim 27.05.2019).

Kızmaz, Zahir. "Kriminolojide Yeni Yönelimler: Bütünleşik (Integrated) Suç Kuramlar1-I”. Fırat Üniversitesi Sosyal Bilimler Dergisi. 15/2 (2005): 349-377. (erişim 27.05.2019).

Korsgaard, Steffen. "Entrepreneurship as Translation: Understanding Entrepreneurial Opportunities through Actor-Network Theory". Entrepreneurship \& Regional Development. 23 (2011): 661-680. (erişim 27.05.2019).

Latour, Bruno ve Stewe Woolgar. Laboratory Life: The Construction of Scientific Facts. Princeton: Princeton University Press, 1986.

Latour, Bruno. “Tarde ve Toplumsalın Sonu”. Çev., Firat Berksun, Emre Koyuncu ve P. Burcu Yalım. Tesmeralsekdiz. 2/3 (2008): 34-49. (erişim 27.05.2019).

Latour, Bruno. Reassembling the Social: An Introduction to Actor-Network-Theory. Oxford: Oxford University Pres, 2005.

Malla Mahmoud, Mohammad. "Bir Mimari Tasarım Sürecinin Aktör Ağ Teorisi ile Okunması”. Yüksek Lisans Tezi, İstanbul Teknik Üniversitesi, 2015.

McDougall, Allan, Elizabeth Anne Kinsella, Mark Goldszmidt, Karen Harkness, Patricia Strachan and Lorelei Lingard. "Beyond the Realist Turn: A Socio囚Material Analysis of Heart Failure Self囚Care”. Sociology of Health \& Illness. 40/1 (2018): 218-233. (erişim 27.05.2019).

Merriam, Sharan B. Nitel Araştırma: Desen ve Uygulama İçin Bir Rehber. Çev. ve ed. Selahattin Turan. Ankara: Nobel Akademik Yayıncılık, 2013.

Mevzuat Bilgi Sistemi. “Türk Ceza Kanunu”. Erişim 26 Mayıs, 2019. http://www. mevzuat.gov.tr/MevzuatMetin/1.5.5237.pdf.

Miles, Jeffrey A. “Aktör A ̆g Kuramı”. Yönetim ve Organizasyon Kuramları. Çev., De- 
niz Yetkin Aker. Haz., Mustafa Polat ve Korhan Arun. Ankara: Nobel Akademik Yayıncilık, 2016.

Mollaer, Fırat. "Bir Türkiye Alegorisi: Şahsiyet Dizisi Üzerine”. Erişim 26 Mayıs, 2019. http://www.birikimdergisi.com/guncel-yazilar/9063/bir-turkiye-alegorisi-sahsiyet-dizisi-uzerine\#.XGX_6ugzZPY.

Mollaer, Fırat. Yerliciliğin Retoriği. Ankara: Phoenix Yayınevi, 2018.

Mutlu, Arif. “Şahsiyet: 'Bu Dizide AKP Yokmuş Gibi Davranıyoruz”, https://gazetehayir.com/sahsiyet-bu-dizide-akp-yokmus-gibi-davraniyoruz-arif-mutlu/amp/.

Odabaş, Zuhal Yonca ve Ertong, Günnur. "Social Effects of Disasters as Actants: A Comparison of 1999 Marmara Earthquake, Turkey and 2004 Tsunami”, Ankara Üniversitesi Çevrebilimleri Dergisi. 3/2 (2011): 47-54. (erişim 26.05.2019).

Odabaş, Zuhal Yonca. Sürdürülebilir Afet Yönetimi ve Kadın. Ankara: Ankara Üniversitesi Rektörlüğü Yayınları, 2010.

ODTÜ Medya Müzik Ödülleri. Erişim 26 Mayıs, 2019. https://neizledik.com/odtuden-sahsiyet-ve-sebnem-bozokluya-odul/.

Özbaş Anbarlı, Züleyha. “Dijital Televizyon Dizilerinde Hegemonik Erkeklik”. Erciyes İletişim Dergisi. 1 (2019): 81-104.

Özdemir, Özlem. “Şahsiyet: İki Yalnız İnsanın Hikayesi”. 221B Dergisi. 15 (2018): 24-28.

Özden, Zafer. Film Eleştirisi: Film Eleştirisinde Temel Yaklaşımlar ve Tür Film Eleştirisi. İmge Kitabevi, 2014.

Polat, Gözde Dalan. “Alzheimer Hastalığının Antropolojisi”. Yüksek Lisans Tezi, Yeditepe Üniversitesi, 2013.

"PuhuTV Yardım Merkezi”. Erişim 26 Mayıs, 2019. https://puhutv.com/yardim-merkezi.

Ritzer, George. Modern Sosyoloji Kuramları. Çev., Himmet Hülür. Ankara: De Ki Basım Yayım, 2013.

Rodríguez-Giralt, Israel. "Social Movements as Actor-Networks: Prospects for a Symmetrical Approach to Doñana's Environmentalist Protests”. Convergencia Revista de Ciencias Sociales. 56 (2011): 13-35. (erişim 26.05.2019).

Ryan, Michael. "Sinema Politikaları: Söylem, Psikanaliz, İdeoloji”. Çev., Hakan Erkılıç. Sinecine. 6/2 (2015): 77-90. (erişim 26.05.2019).

Sayar, Tahsin Eren ve Banu Sayar. "Black Mirror Dizisi ‘The National Anthem’ Bölümü'nün Gündem Belirleme Kuramı Üzerinden İncelenmesi”. Stratejik ve Sosyal Araştırmalar Dergisi. 2/1 (2018): 49-60. (erişim 26.05.2019).

Seçilmişler, Töre ve Zekiye Yenen. "Koruma Sorunsalına İlişkin Kuramsal Bir Değerlendirme: Kurumsalcı (Alan Yönetimi) ve Çoğulcu (Aktör Ağ Teorisi) Yaklaşımların Karşılaştırması”. Yıldız Teknik Üniversitesi Fen Bilimleri Enstitüsü Doktora Tezlerinden Üretilmiş Yayınlar. 3 (2011): 375-384. (erişim 26.05.2019).

Seçilmişler, Töre. "Koruma Öncelikli Alanlarda Aktör Ağın Çözümlenmesi ve Betimlenmesi: İstanbul Tarihi Yarımada Örneği”. Yüksek Lisans Tezi, Yıldız Teknik Üniversitesi, 2010. 
Selekler, Kaynak. “Alois Alzheimer ve Alzheimer Hastalığı”. Türk Geriatri Dergisi. 13 (2010): 9-14. (erişim 26.05.2019).

Slattery, Martin. Sosyolojide Temel Fikirler. Çev., Özlem Balkız, Gülhan Demiriz, Hacer Harlak, Cevdet Özdemir, Şebnem Özkan ve Ümit Tatlıcan. Ankara: Sentez Yayıncilık, 2017.

Şahin, Arzu. “Unutmak En Büyük Cinayettir”. Hayal Perdesi. 65 (2018): 58-61.

Şahsiyet Blog. Erişim 26 Mayıs 2019, https://neokudumneizledim. blogspot. com/2018/11/dizi-incelemesi-sahsiyet.html.

“Şahsiyet Dizisi Bahisleri”. Erişim 26 Mayıs, 2019. https://www.bilemezsin.com/ailemizin-seri-katili-icimizden-biri-agah-beyoglu-4-bolumde-sadece-1-kisiyi-oldurecek--50080.

“Şahsiyet Dizisi İzlenme Sayısı”. Erişim 15 Aralık, 2019. https://www.ntv.com.tr/ sanat/emmy-odulu-sahsiyete-ilgiyi-20-kat-artirdi-puhutvde-ucretsiz-izle,uXf_ MYPdg025Ole1hQxcKA.

“Şahsiyet Dizisi Meksika’ya Uyarlanıyor”. Erişim 26 Mayıs, 2019.https://neizledik. $\mathrm{com} /$ sahsiyet-dizisi-meksikaya-uyarlaniyor/.

Şahsiyet Dizisi Satış Sayısı. Erişim 15 Aralık, 2019, https://www.birgun.net/haber/ haluk-bilginer-e-odul-kazandiran-sahsiyet-dizisi-hakkinda-bilmeniz-gerekenler-277757.

“Şahsiyet Dizisinin Müzikleri Listelerde Üst Sıraları Zorluyor!”. Erişim 26 Mayıs, 2019.http://www.ranini.tv/haber/30567/1/sahsiyet-dizisinin-muzikleri-listelerde-ust-siralari-zorluyor.

Şahsiyet IMDb. Erişim 17 Aralık, 2019. https://www.imdb.com/title/tt7920978/.

Şahsiyet Instagram. Erişim 27 Şubat, 2020. https://www.instagram.com / sahsiyetdizi/?hl=tr.

Şahsiyet PuhuTV. Erişim 27 Şubat, 2020. https://puhutv.com/sahsiyet-detay.

Şahsiyet Twitter. Erişim 26 Mayıs, 2019. https://twitter.com/ sahsiyetdizi/status/ 975092349863940097.

Şeker, Şadi Evren. “Aktör Ăg Teorisi (Actor Network Theory)”. YBS Ansiklopedisi. 1/1 (2014): 14-15. (erişim 26.05.2019).

T.C. Adalet Bakanlığı. “Adli İstatistikler 2018”. Erişim 26 Mayıs, 2019. http://www. adlisicil.adalet.gov.tr/istatistik_2018/istatistik2018.pdf.

Tatlı, Öykü. “Türk Seri Katil Dizisi”. Erişim 26 Mayıs, 2019. https://unifestal.com/ seriefilm/turk-seri-katil-dizisi-sahsiyet/.

TDK. “Agah”. Erişim 3 Şubat, 2019. http://www.tdk.gov.tr/index.php?option=com_ bts\&view=bts\&kategori1 $=$ veritbn\&kelimesec $=4270$.

Tecim, Erhan. Sağlık Sosyolojisi. Konya: Çizgi Kitabevi, 2018.

Topal, Çağatay. "Meta Fetişizmi: Latourcu Bir Okuma Denemesi”. Mediterranean Journal of Humanities. 7/2 (2017): 423-435. (erişim 26.05.2019).

Torun, Tolga ve Özüm Eğilmez. "Yerleşiklik ve İlişkileri Anlamada Ağ Düzeneği Kuramı: Sosyolojik Bakış”. Dumlupınar Üniversitesi Sosyal Bilimler Dergisi. 42 (2014): 69-76. (erişim 26.05.2019). 
Tutgun-Ünal, Aylin. "Sosyal Medya Bağımlılığı: Üniversite Öğrencileri Üzerine Bir Araştırma”. Doktora Tezi, Marmara Üniversitesi, 2015.

Türk Tip Öğrencileri Birliği. Erişim 26 Mayıs, 2019. https://fav10.net/forum/threads/ t\%C4\%B1p-\%C3\%96\%C4\%9Frencilerinden-\%C5\%9Eahsiyete-\%C3\%96d\% C3\% B Cl.286425/.

Westworld Dizisi. "Westworld”. Erişim 29 Şubat, 2020. https://www.hbo.com/ westworld.

Yetişkin, Ebru. "Bir Başka Laboratuvar: B(Ağ)Sal Kürasyon”. Toplum ve Bilim. 144 (2018): 38-68.

Yin-Yang. Erişim 26 Mayıs, 2019. https://tr.wikipedia.org/wiki/Yin_ile_yang.

"YTÜ İşletme Kulübü 17. Yılın Yıldızları Ödülleri”. Erişim 19 Kasım, 2019. https:// www.ayyapim.com/tr-tr/odullerimiz.

Yuvayapan, Emel. "Sinemada Suç ve Ceza-Modern Toplumlarda Adalet Arayışının Sinemada Temsili”. Yüksek Lisans Tezi. Dokuz Eylül Üniversitesi, 2006.

Zizek, Slavoj. "Sunuş: Toplumsalın Kalbindeki Film”. Filmlerle Sosyoloji. Yaz. Bülent Diken ve Carsten B. Laustsen. Çev., Sona Ertekin. İstanbul: Metis Yayınları, 2016.

"2019 International Emmy Awards”. Erişim 15 Aralık, 2019. https://www.iemmys. tv/2019-international-emmy-winners-announced-at-gala-in-new-york/. 


\title{
Actor Network, Health-IIIness and Crime: A Discussion over Sahsiyet (Persona) Mini-Series
}

\author{
ALI GÜNDÜZ
}

GÜNNUR ERTONG ATTAR

\begin{abstract}
This study evaluates the transformation of a subject's network through illness and murder and investigates this transformation in the context of the Actor Network Theory and with the example of Persona (Sahsiyet) mini-series. The main motivation of the research originates from the transformation of an individual experience into a social influence and from the possibility that the fiction in Persona may turn into reality in any time. Departing from Diken and Laustsen's ${ }^{127}$ principle of "When we talk about film, we talk about society.", the study approaches the evolution of illness into serial murder from the biopsychosocial point of view and through Merton's concept of crime that builds upon strain. The results show that an illness may have radical effects on an individual's life and that accumulating social and institutional fractures such as ignoring in justices may cause individual quests for justice by turning into deep social wounds.
\end{abstract}

Keywords: Actor Network Theory, Sahsiyet (Persona) mini-series (2018), Sociology of health and illness, Alzheimer, Individual quests for justice. 